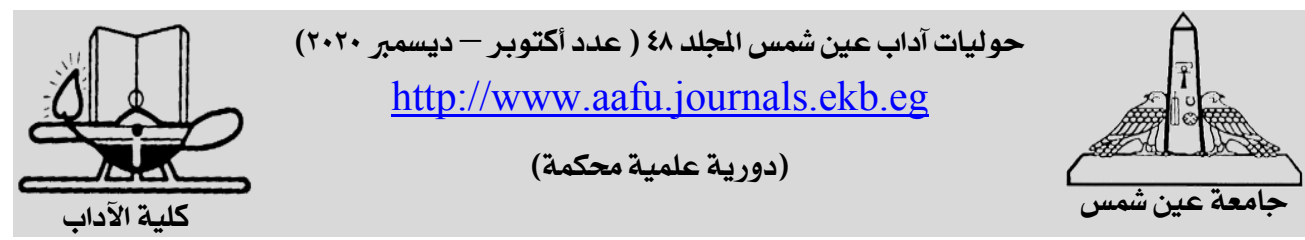

\title{
المركة الماسونية
}

\section{عرض ومناقشة}

* منصور بن عبد العزيز الحجيلي

كلية الآداب و العلوم الإنسانية - قسم الدراسات الإسلامية - الأستاذ المشارك في العقيدة والمذاهب المعاصرة

ationd|

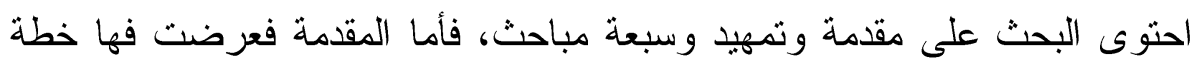
البحث وطريقته و أهميته، و أما التمهيد فقد وطأت فيه للبحث وبيان سرية و غموض هذه

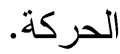

ثم كان المبحث الأول عن تعريف الماسونية، في حيث التعريف اللفظي، وأن لفظ

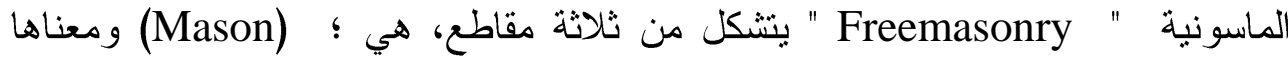

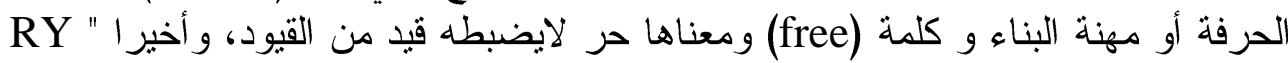

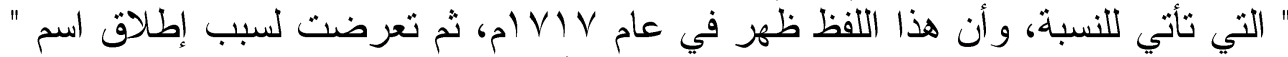

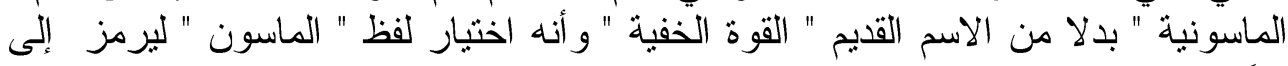

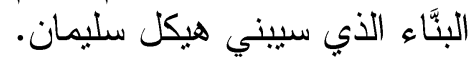
ثم كان التعرف للماسونية كمنظمة، وبيان أوان المؤيدين و المعارضين، وتم

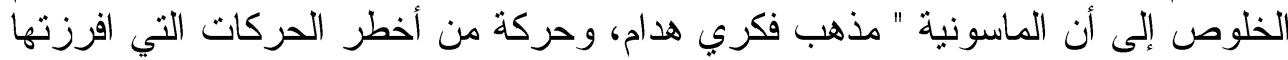

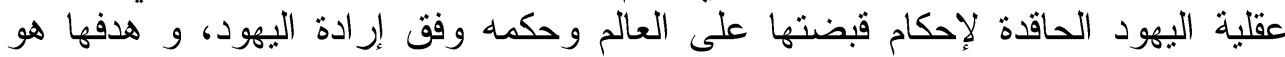
الحفاظ على الإنسان اليهودي وتمكينه من السيطرة على مسار الإنى المجنمعات الإنسانية

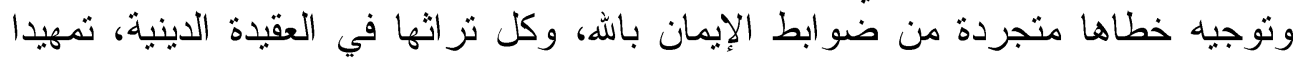

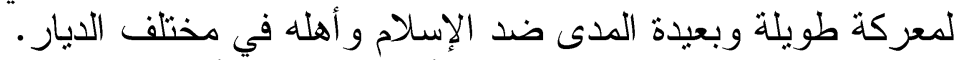

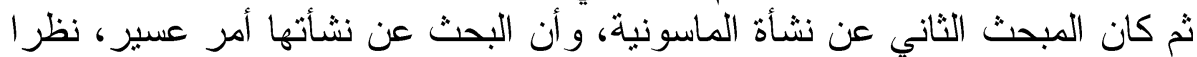
لكون هذه المنظمة سرية وتبالغ في إخفاء أور اقها.

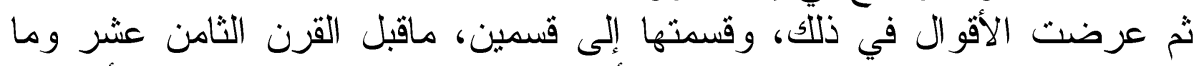

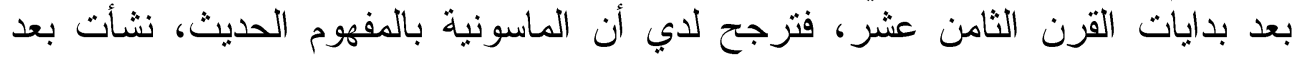

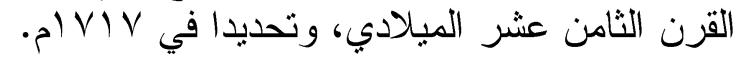

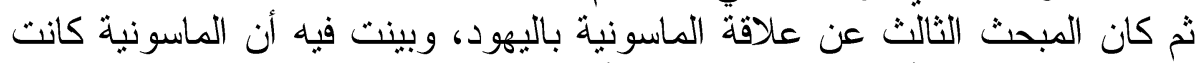

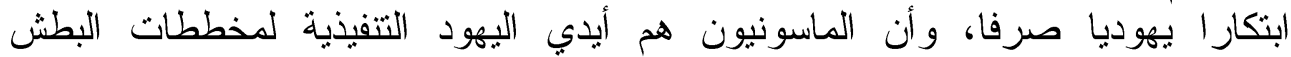

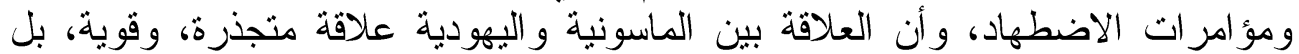

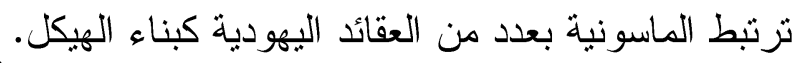

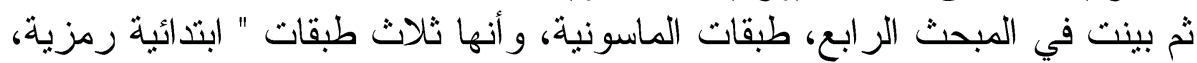

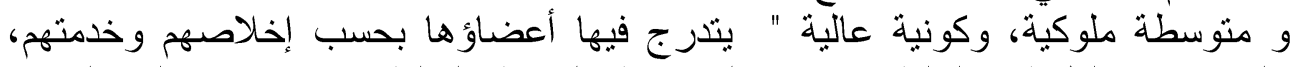

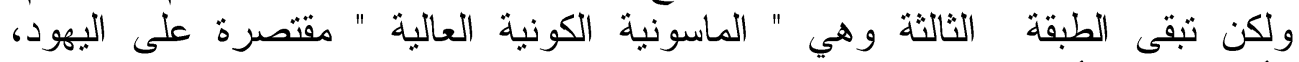
و أعضائها هم أعضاء المحافل الماسونية الملوكية. 
ثم كان المبحث الخامس عن عقائد الماسونية، و أنها عقائد تسعى لإحداث انقسام بين

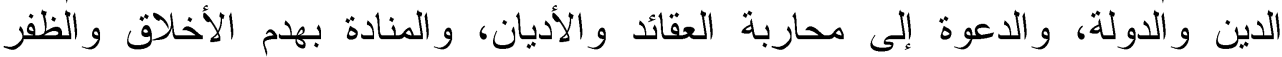
بالحرية البهيمية، و إعلان السخط على الثرائع التئي تحد من الانطلاق.

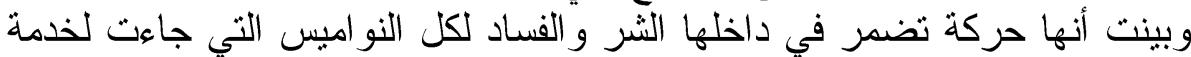

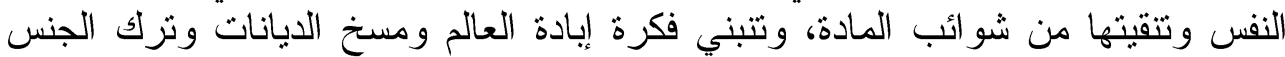

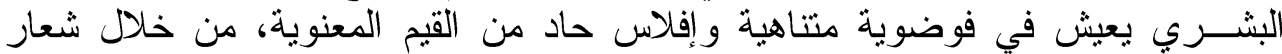
المثلث وهو " الحرية، المساو اة، الإخاء.

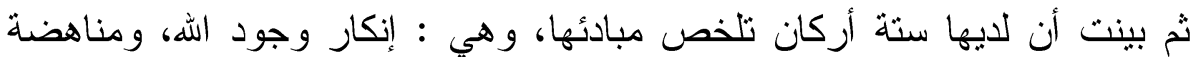
الأديان، ومحاربة رجال الدين، و الإباحية و الإفساد، وكره الوطن، وهان وهدم البشرية. و وأن

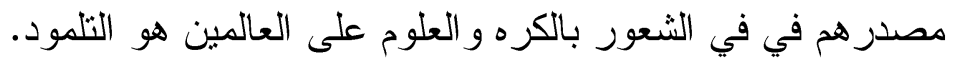

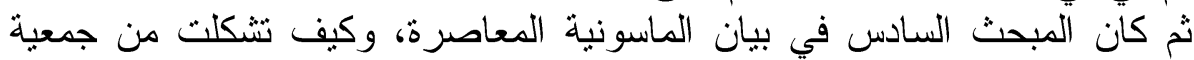
تحارب النصر انية فيما قبل القرن السابع عشر، إلى جمعية مختلفة تماما في بداية القرن

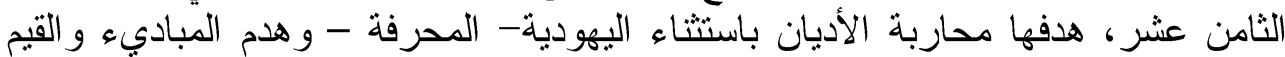

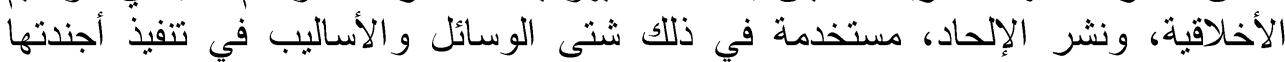

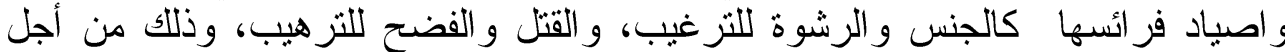
إقامة مملكة اليهود و إعادة بناء هيكل سليمان.

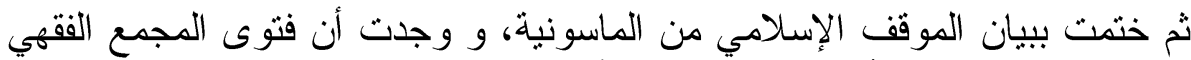
الإسلامي، و لجنة الفتوى بالأزهر الثريف، قد أجادت ووفت، ونصحت للامة في التحذير

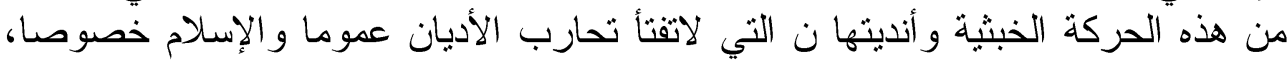

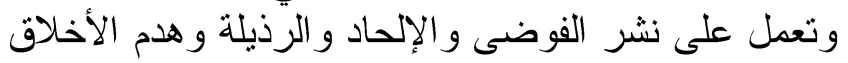




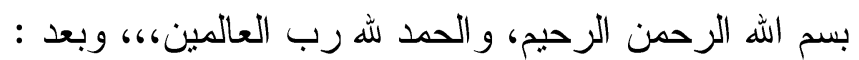

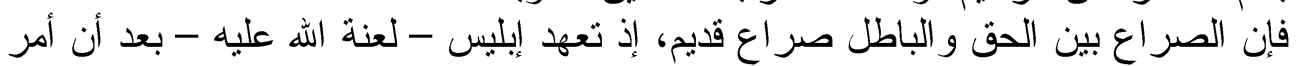

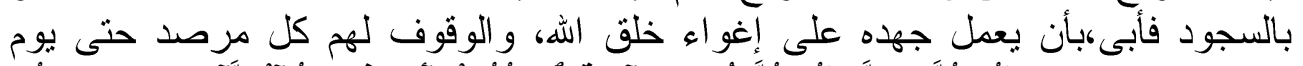

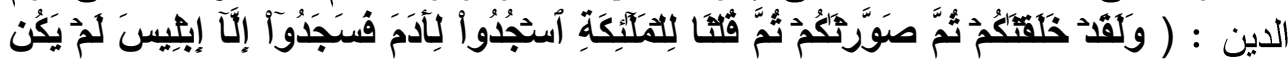

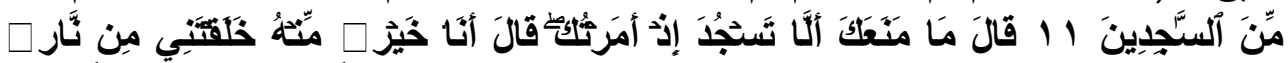

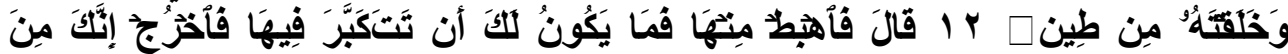

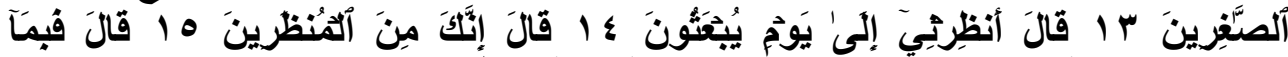

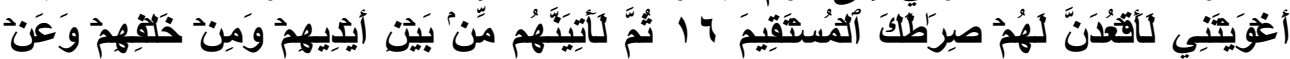

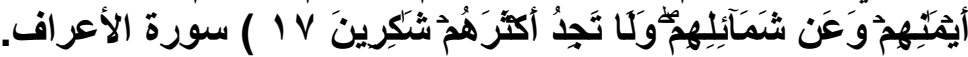

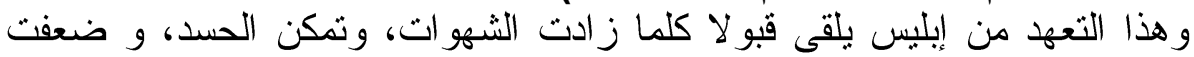
الهمة، وقصر أهل الحق عن بيانه. و إن من أبرز المذاهب الفكرية التي انتشرت في العصن العبر الحاضر ، و أصبحث تتغلغل

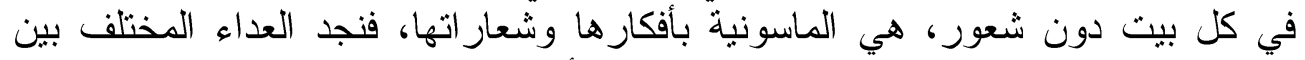

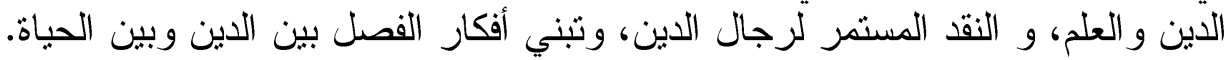

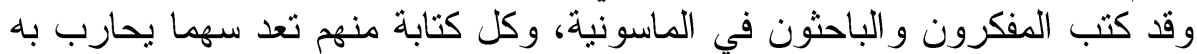

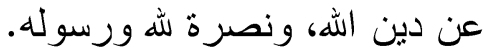

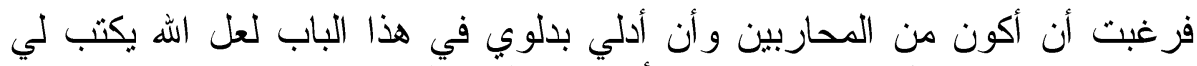
بذلك حسنات يوم لاينفع مال و لابنون إلا من أنى الله بقلب سليم. فكان هذا البحث الموجز في مفهوم الماسونية، سمت نفسها لإن بهذا الاسم وماقصتنه،

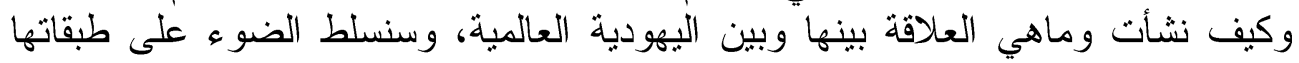

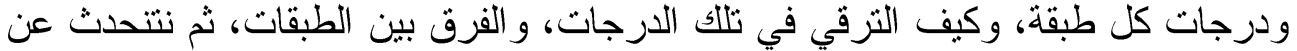
الماسونية المعاصرة و أهدافها ووسائلها ثم نختم بموقف الإسلام من الماسونية وحكمه فيها.

تعبر الماسونية من أبرز وأهم و أذكى عمليات اليهود ضد البشرية و الأديان، فقد

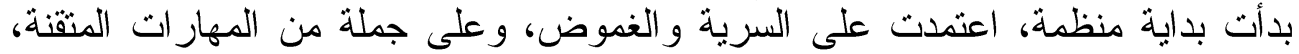

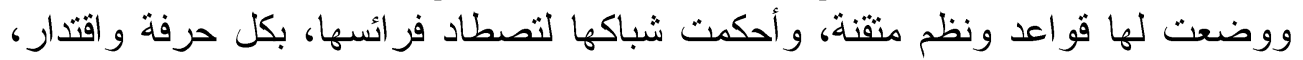

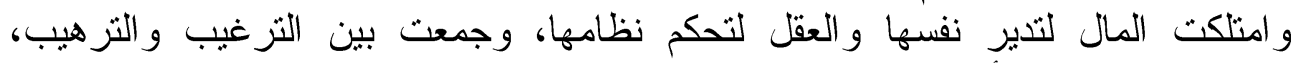
لتضمن عدم الخيانة أو الخروج من نظامها. ولكي تلبس على الناس طبيعتها، تلبست بلباس الخيرية و التسامح، فجعل الداخل في

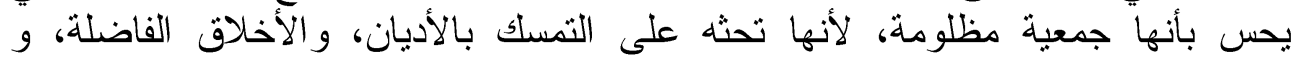

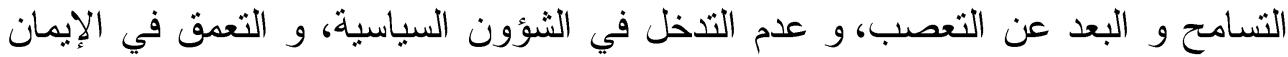

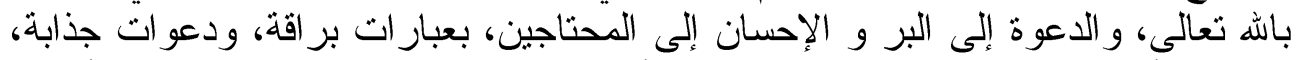

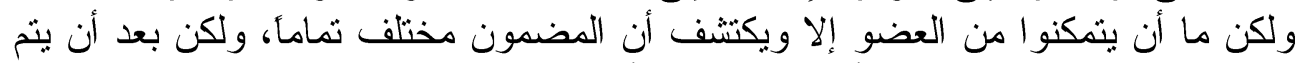

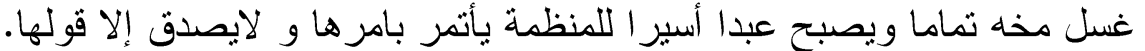

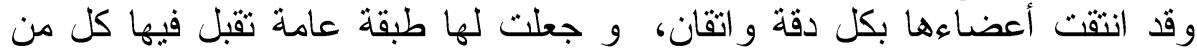

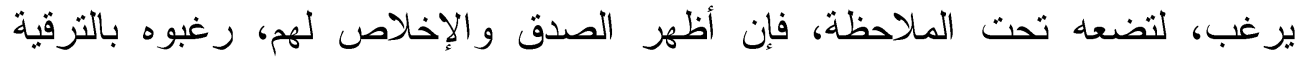
وشرطو التقام بمزيد من الإخلاص و الخضوع، ومن لمست منه التز اخي و التز اجع هددته بالقتل ولربما نفذت التهديد. 


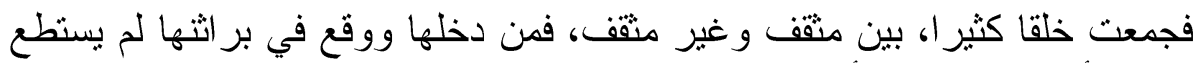

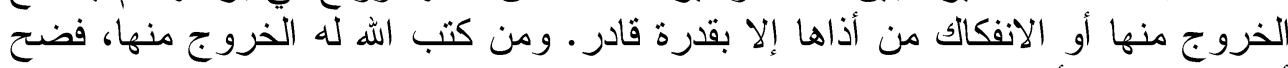

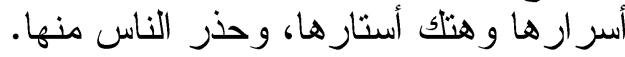

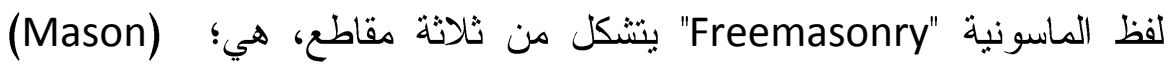

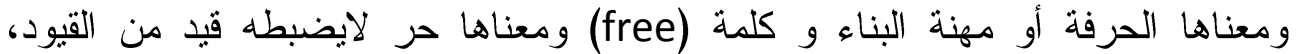

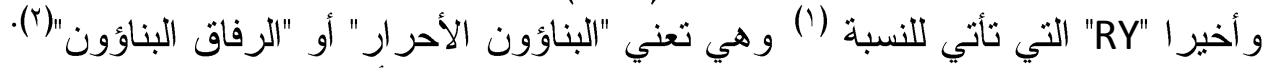

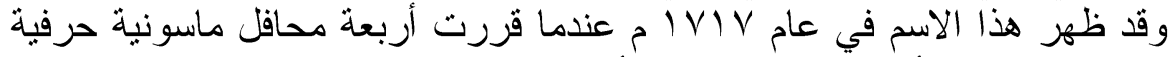

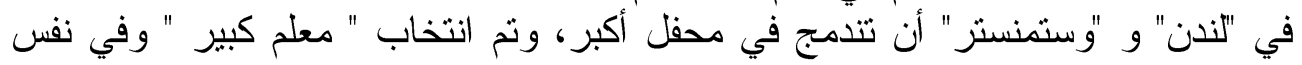

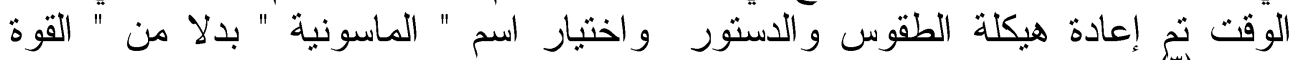
الخفية (ن)

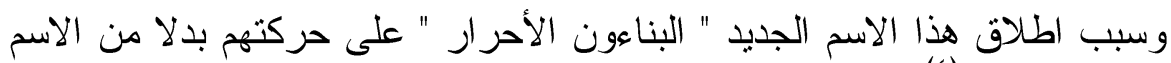

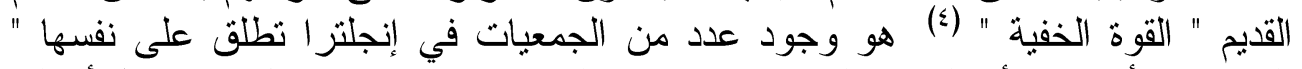

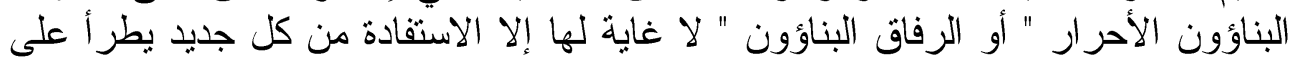

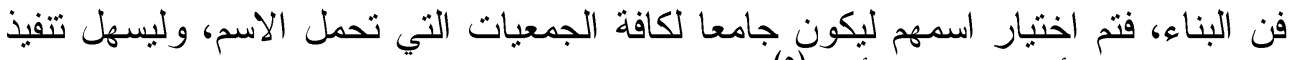

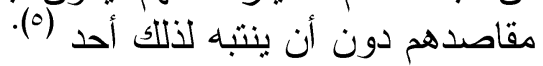

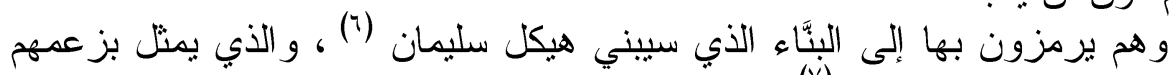

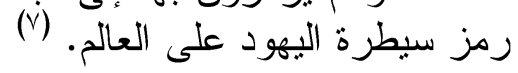

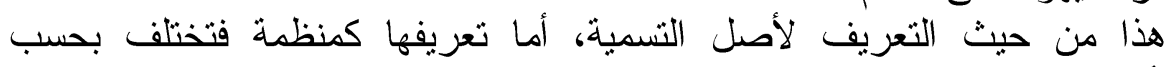
المؤيدين أو المعارضين لها. المؤيدون لها يعتبرون أنها ؛ منظمة خيرية اجتماعية، هدفها التعارف و التعاون،

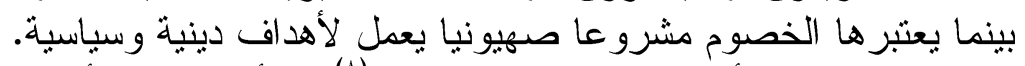

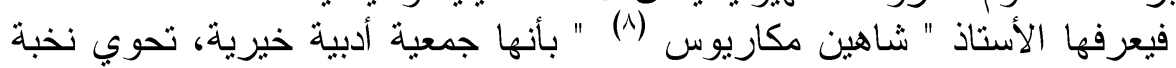

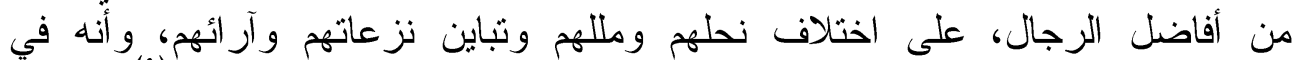

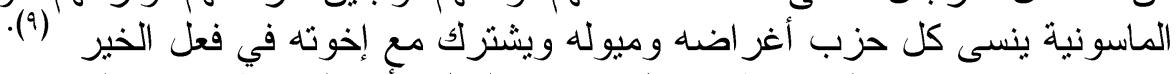

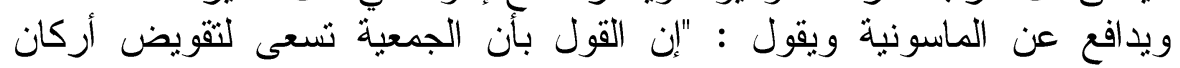

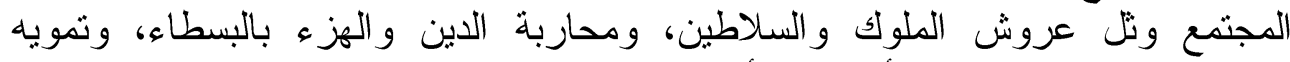

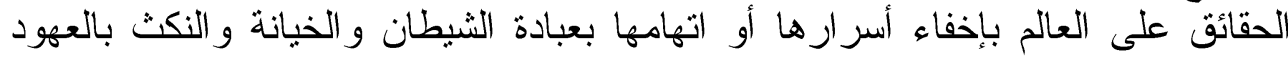

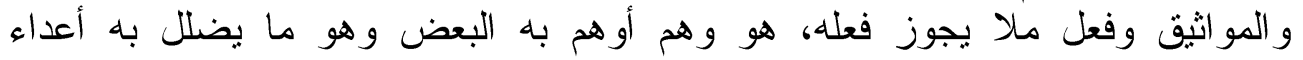

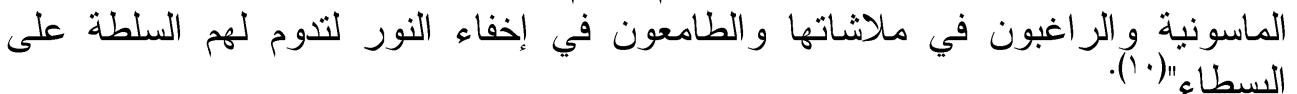

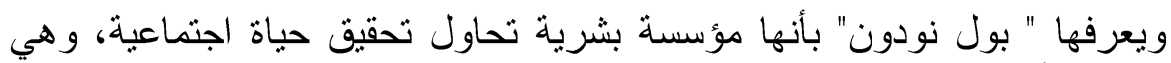

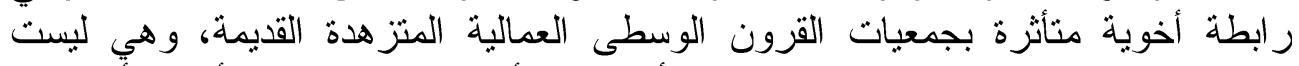
جمعية سرية بل مغلقة فحسب، وقو اعدها الأساسية و أنظتها وتاريخها و أسماء أعضائها معروفة (ii)

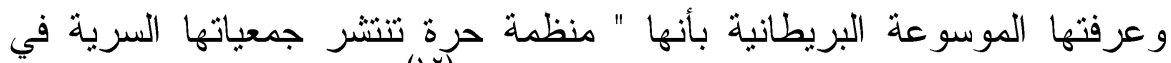

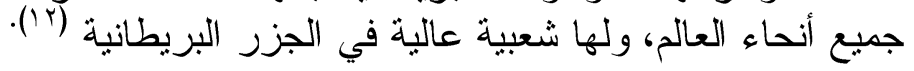




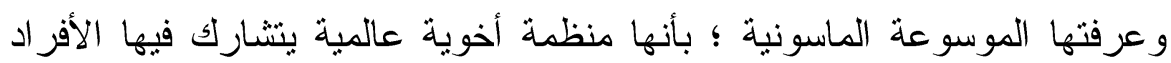

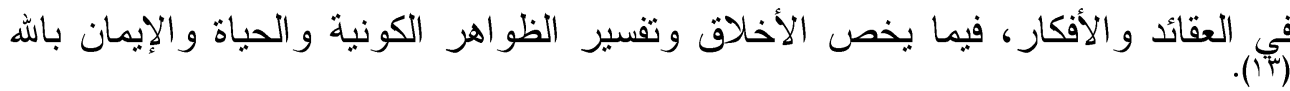

أما المعارضون لها فيرون أنها : منظمة سرية يهودية إرهابية غامضة محكمة

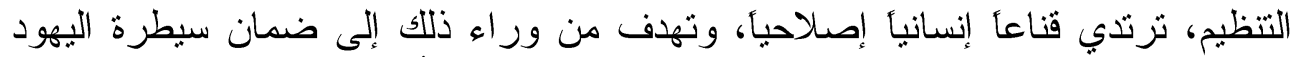

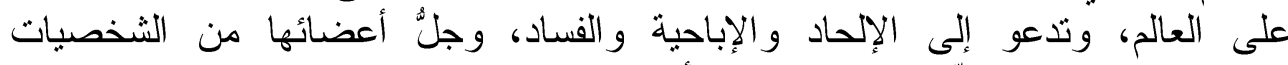

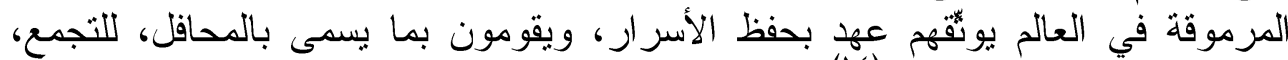

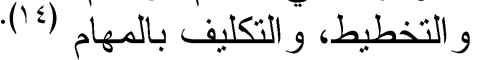

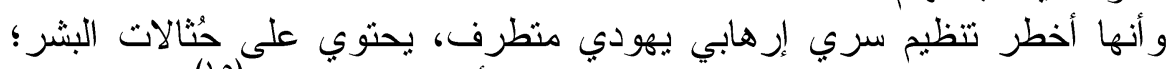

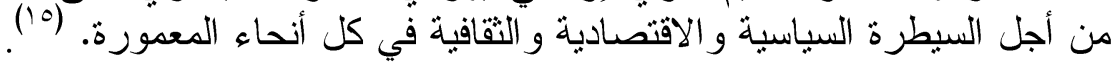

وتعتبر الماسونية حركة من أخطر الحركات التي أفرزتها عقلية اليهود الحاقدة

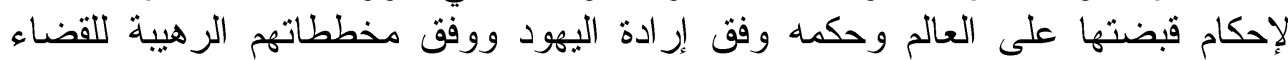

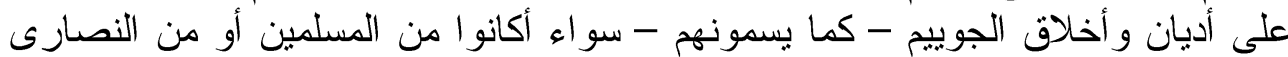

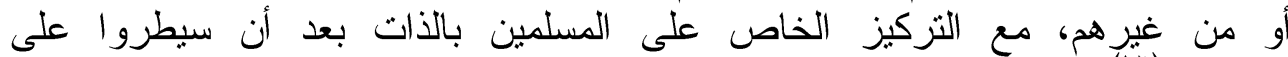
(النصارى (17)

ويسيطر الماسونيون الآن على كثير من بقاع الأرض ولهم ضحايا خدعوا بهم

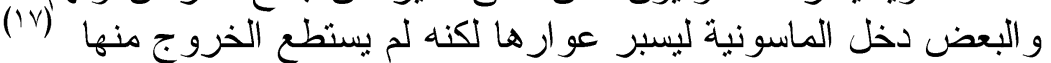

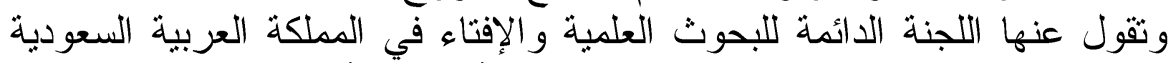

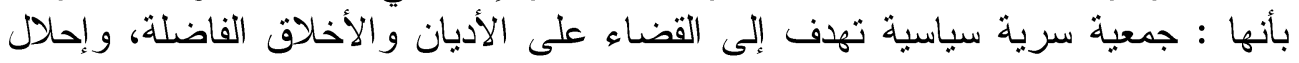
القو انين الوضعية والنظم غير الدينية محلها، وتسعى جهدها في إحداث الفيات انقلابات مستمرة

و إحلال سلطة مكان أخرى بدعوى حرية الفكر و الر أي و العقيدة.

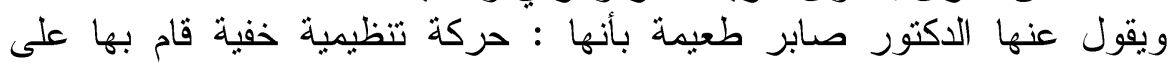

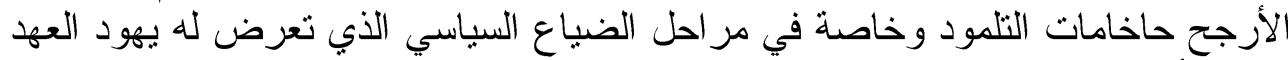

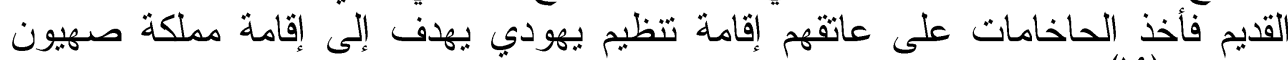

العالمبة. (19) - (19)

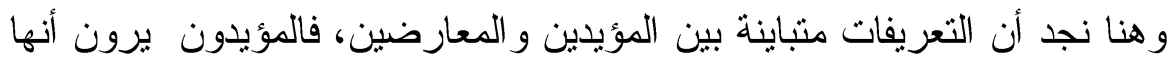

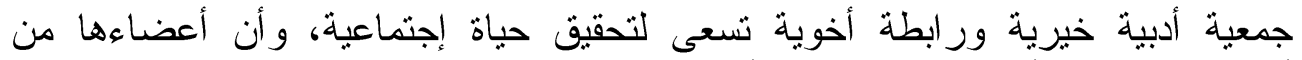

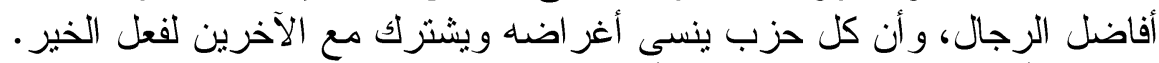

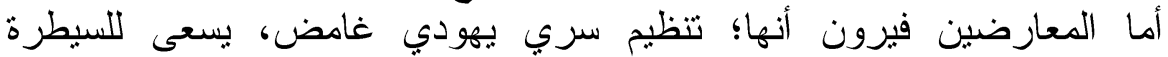

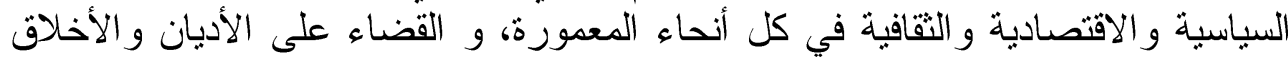

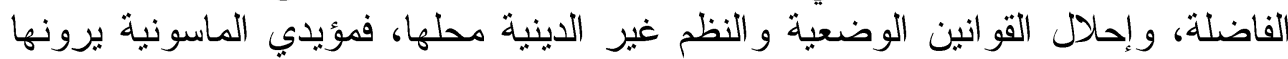

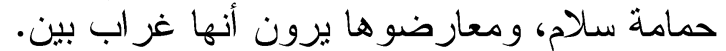

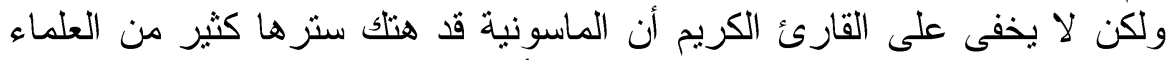

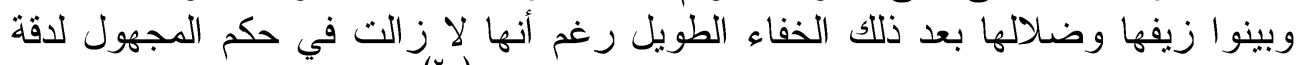

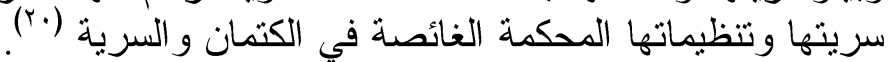

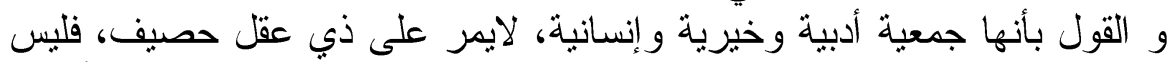

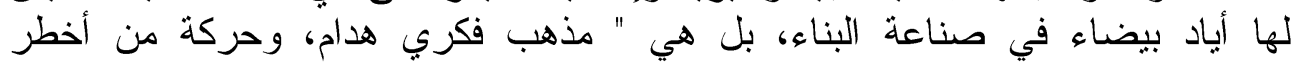

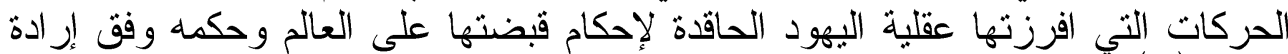

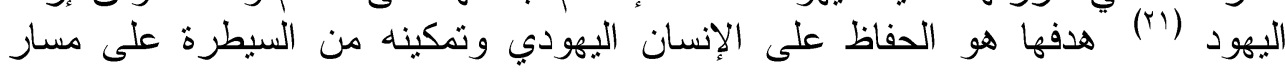


المجتمعات الإنسانية وتوجيه خطاها متجردة من ضو ابط الإيمان بالله، وكل تز اثها في

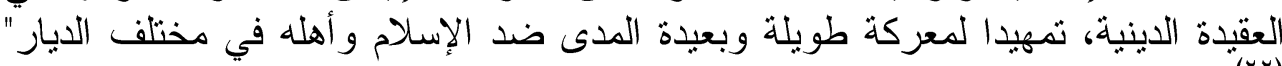

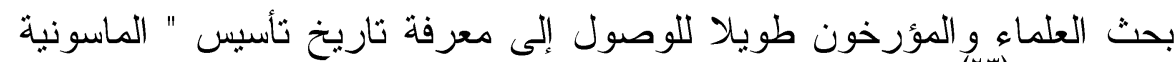

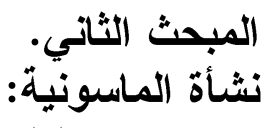

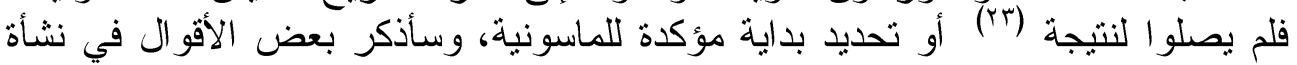
أنها نشأت في التيه في سيناء و أن نبي الله " موسى عليه السلام " كان "أستاذا أعظم الأله

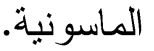

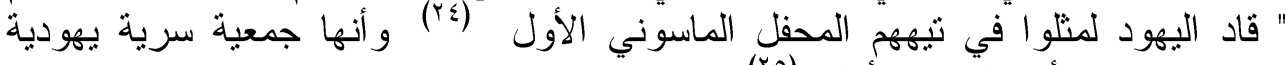

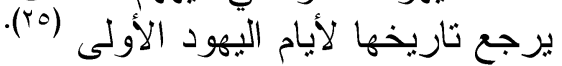

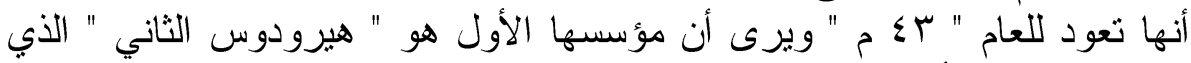

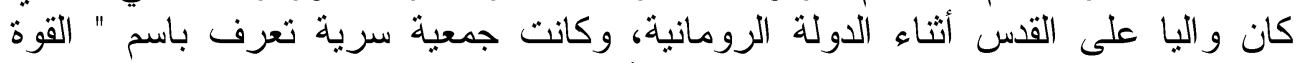

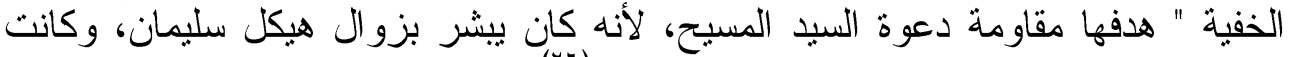

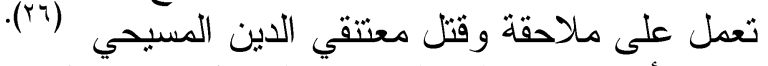

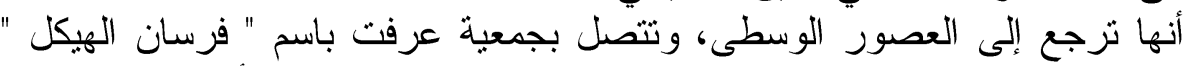

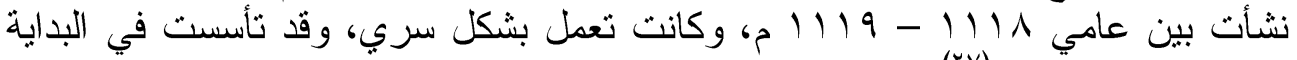

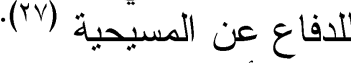
أنها تعود للقرن الثالث عشر الميلادي، حيث كان يطلق المهندسون الإيطاليون لفظ

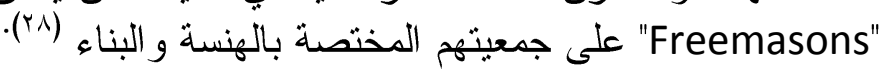

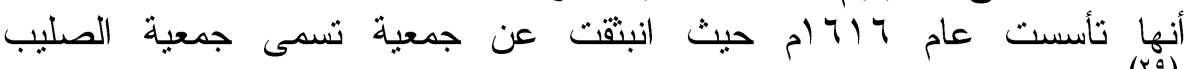
الوردي (ra). (به.

أنها تعود لما قبل القرن الثامن عشر الميلادي، و أنها كانت جمعية خفية وتطلق

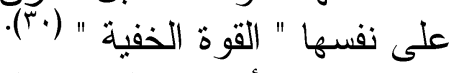

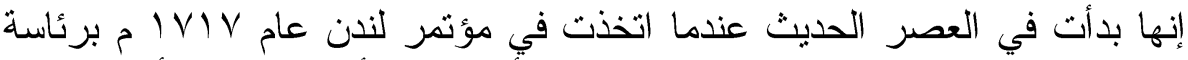

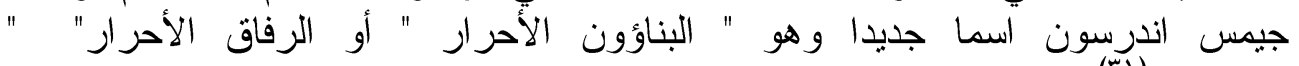

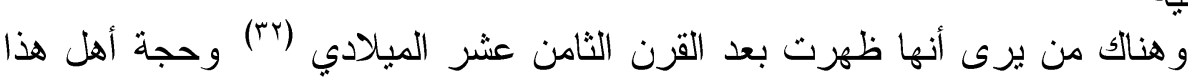
القول أنه لم يكن في بريطانيا في القرن الثامن عشر أية جمعية تحمل اسم البنائين

$$
\text { وهنا راي آخر بقول إنها ظهرت إثر الحروب الصليبية. (r) }
$$

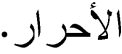

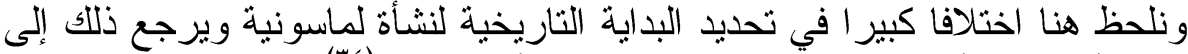

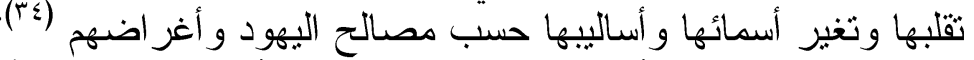

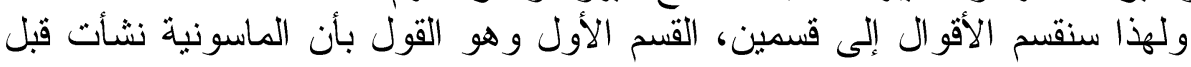
القرن الثامن عشر المبلادي. و القسم الآخر يقول بأن الماسونية نشأت مع بداية القرن الثامن عشر الميلادي.

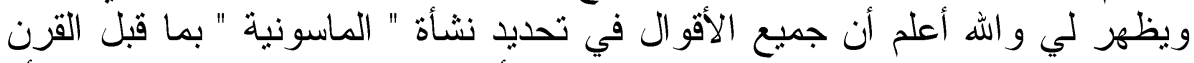

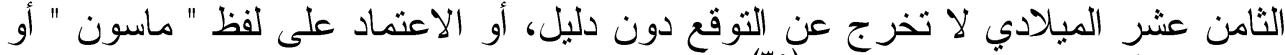

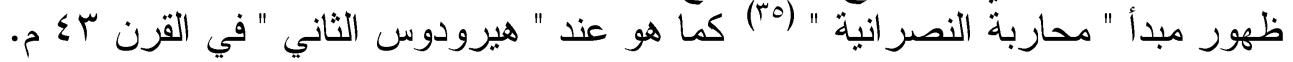


و هذا المفهوم للماسونية، إن اعتبرناه بداية لها فليس لدينا دليل على أن الماسونية

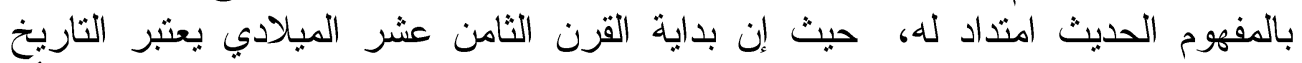

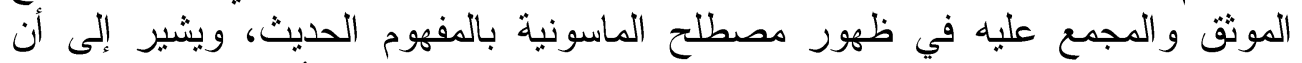

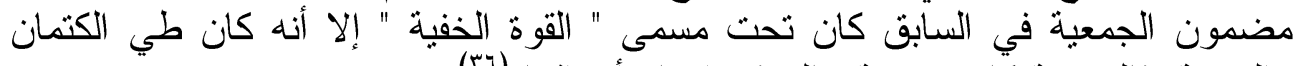

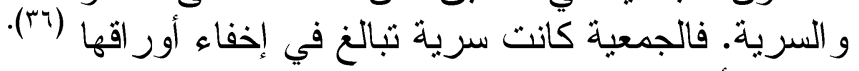

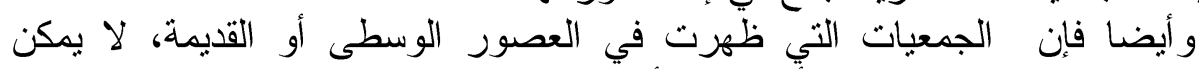

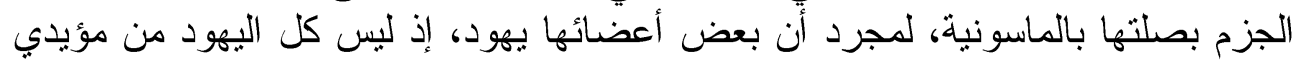

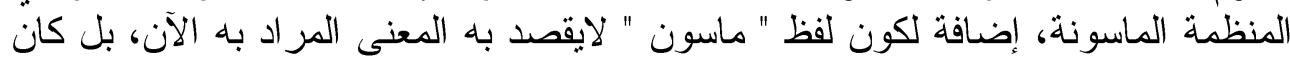

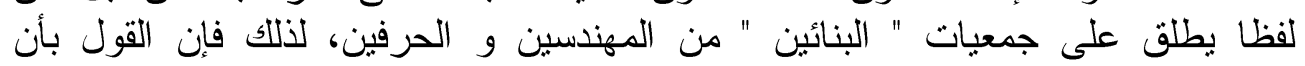

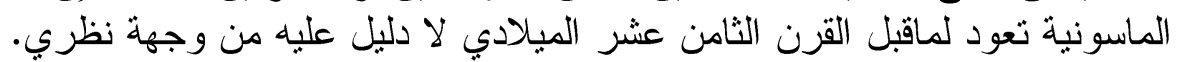

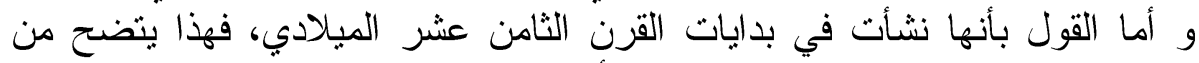

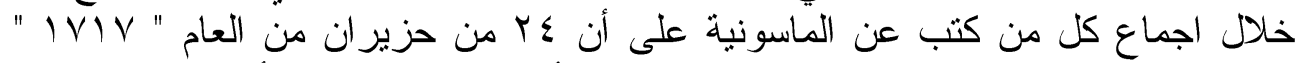

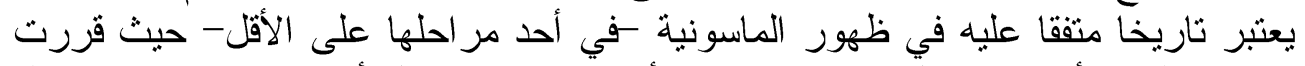

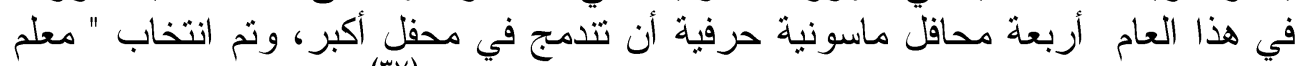

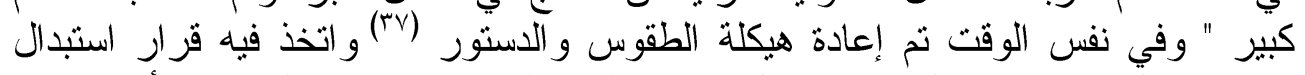

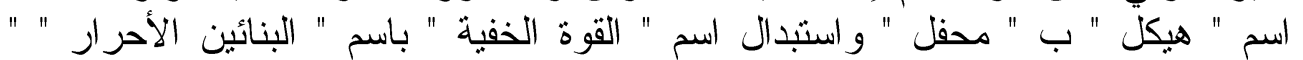
Freemasonry

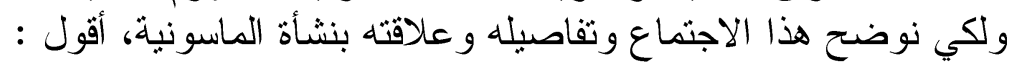
لقد كان لفظ " Masons " موجودا من القرن الثالث عشر المبلادي، و و كان بطلقه

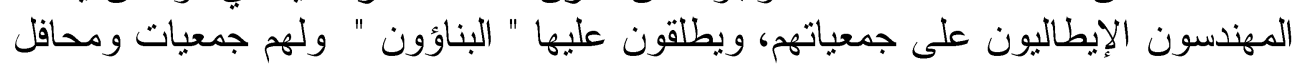

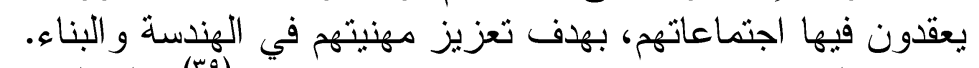

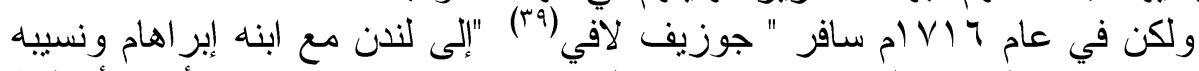

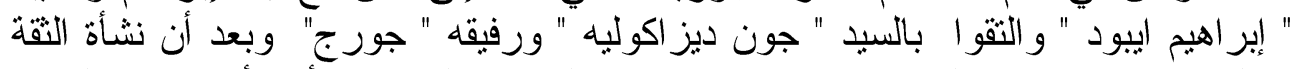

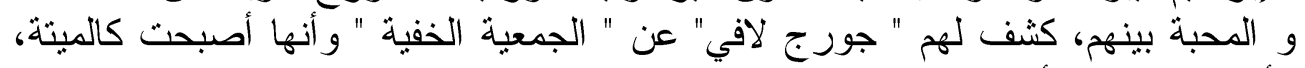

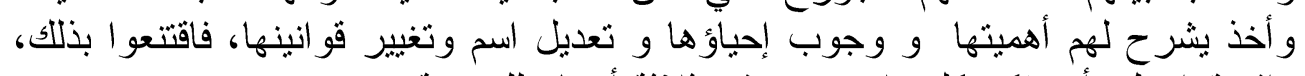
و افترقو ا على أن يفكر كل و احد منهم في ثناثنة أسماء للجمعية.

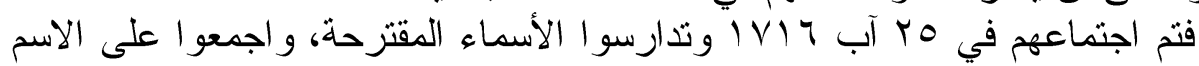

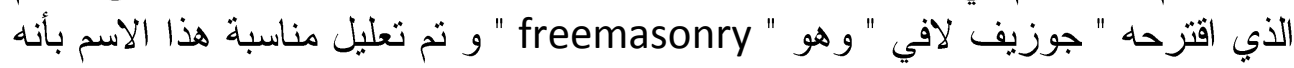

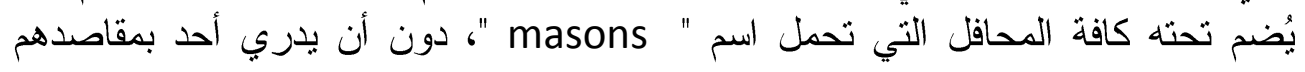

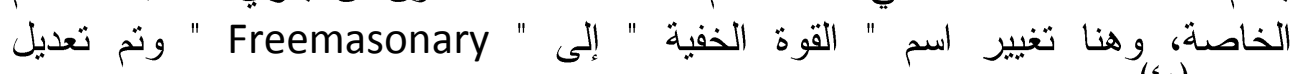
قو انينها (ك)؛

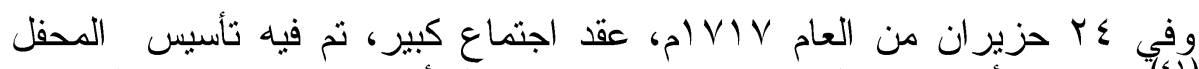

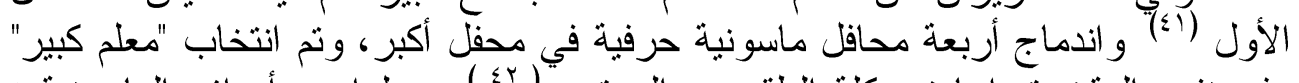

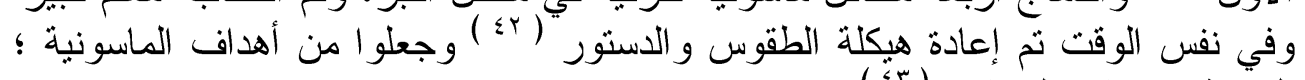

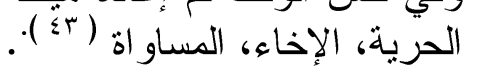

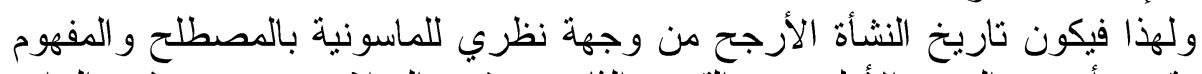

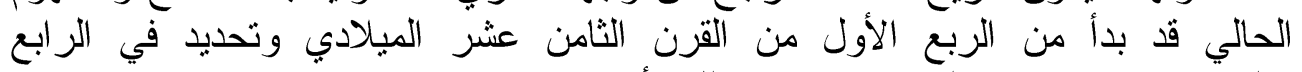

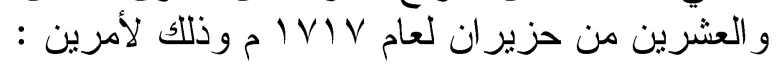


الأول : أن هذا القرن شاعت فيه الفلسفات العقلانية المعادية للكنيسة و الطبقات

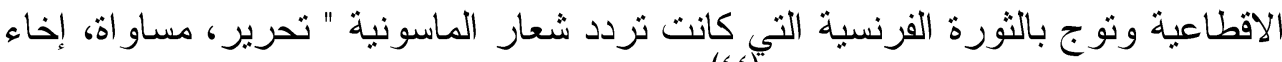

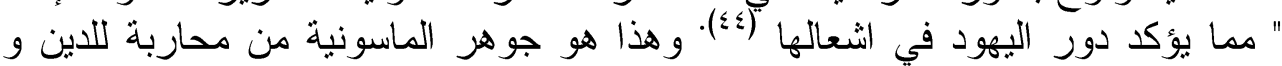
إثارة للفتن و الثور ات التور السياسية.

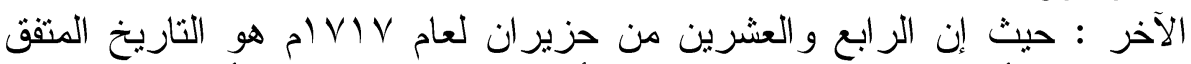

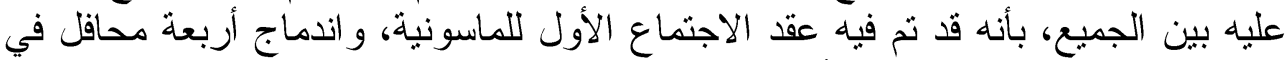
محفل و احد و انشاء " المحفل الأول " و تعديل القو انين، و استبدال لفظ هيكل ب بل " محفل ". المبحث الثالث. علاقة الماسونية باليهود.

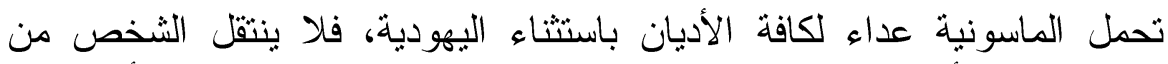

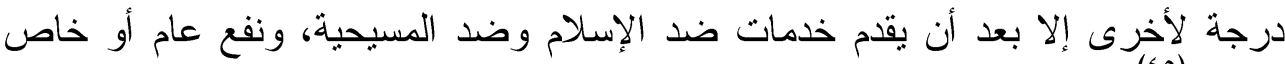
للبهود (؛0) دجرة و تضع الماسونية على وجهها قناعا يخفي حقيقتها، فتظهر بما يخالف نواياها،

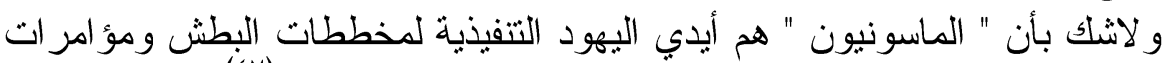

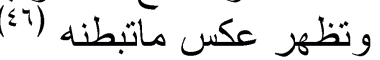

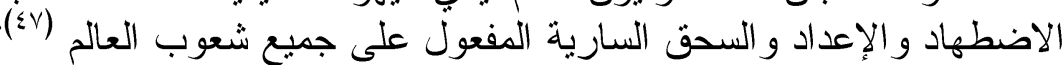

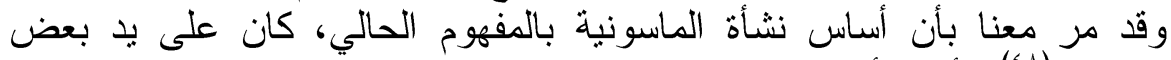

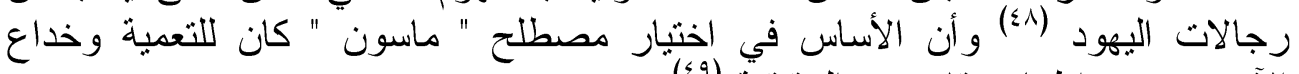

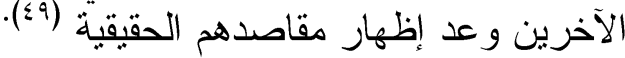
ويقول أحد العارفين بالماسونية : نشأتها في إنجلتر ا وبناء درجاتها نم في فرنسا، وتأهيلها الروحي في ألمانيا، أما مظاهرها هالما الخارجية فقد نشأت في معظمها من اليهودية (01) $(0$.

و على الرغم من محاولة الماسونبين إخفاء حقبقة العلاقة باليهودية العالمية (roان،

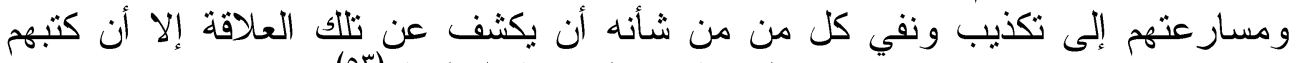

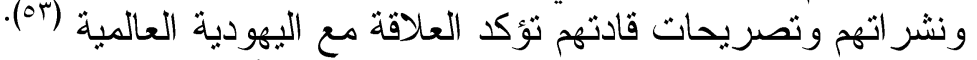

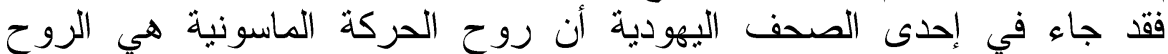

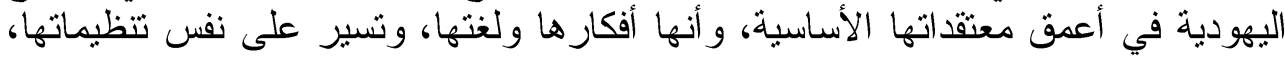

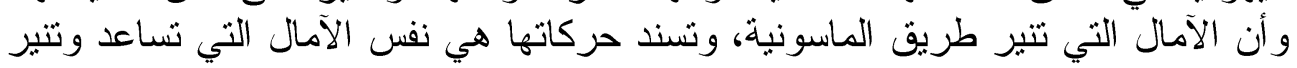

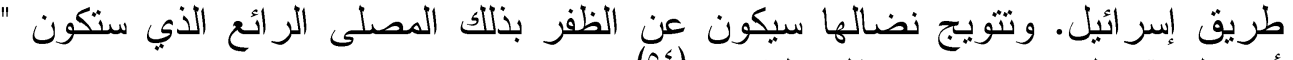

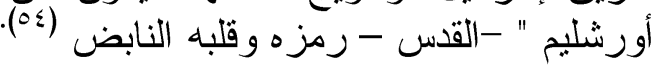

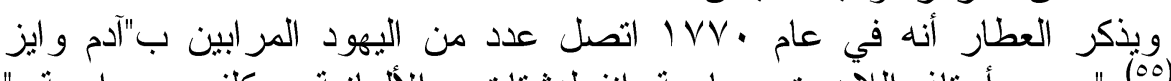

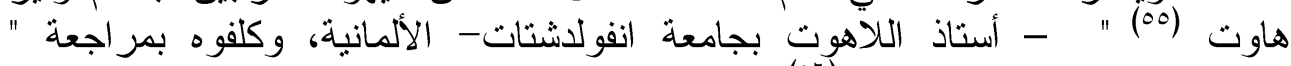

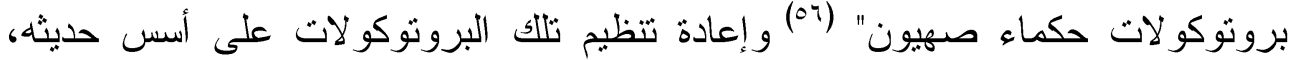

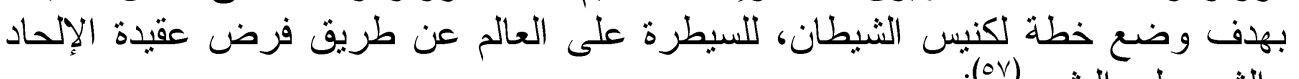
و الشر على البشر خطر (ov).

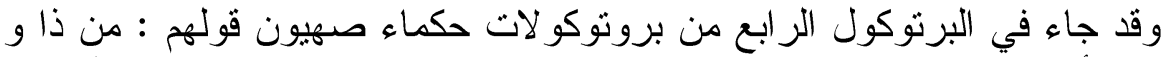

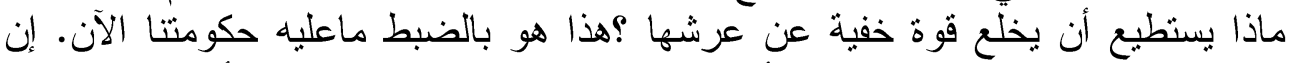

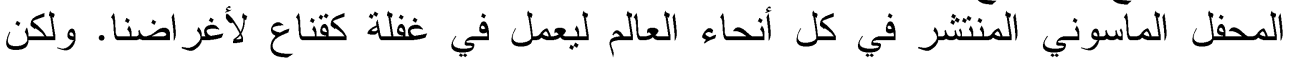

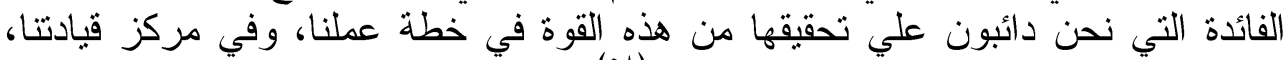

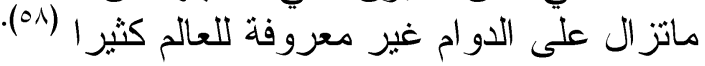


ونرتبط الماسونية ببناء هيكل سليمان، و يتم تبجيل الملك سليمان كراع ومعلم

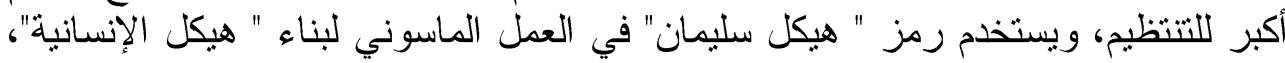

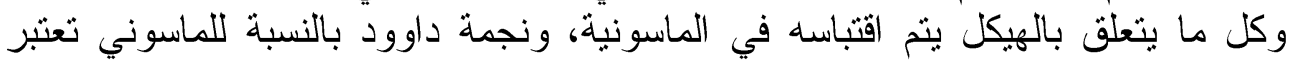

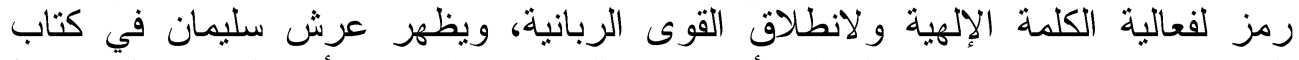

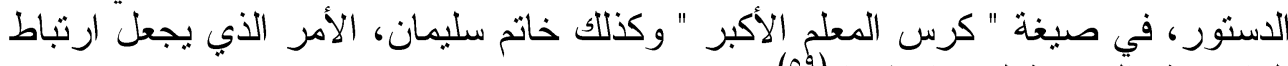

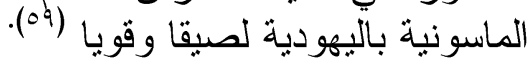

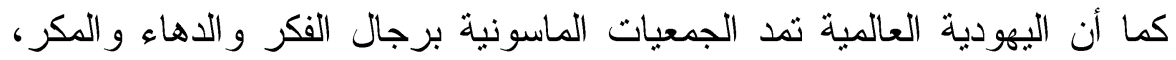

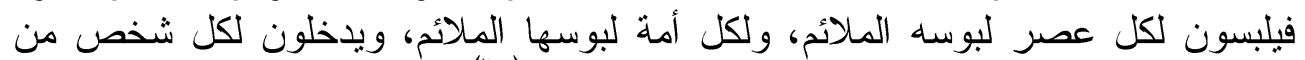

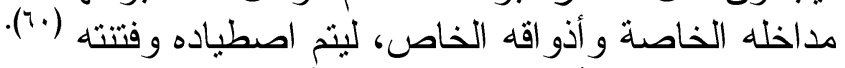

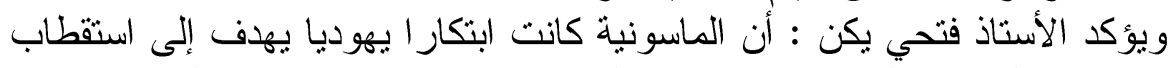

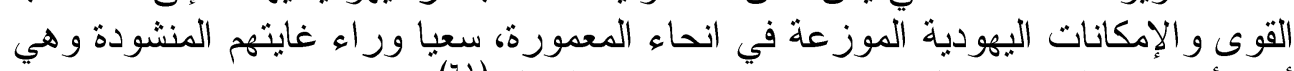

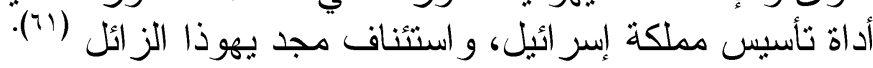

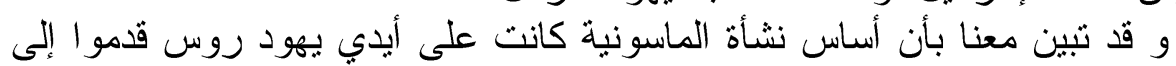

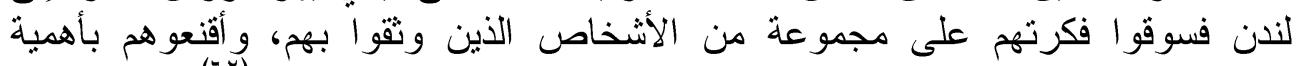

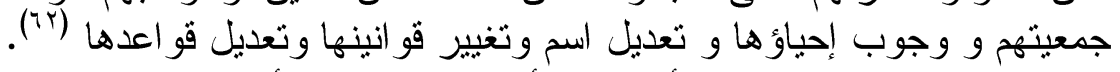

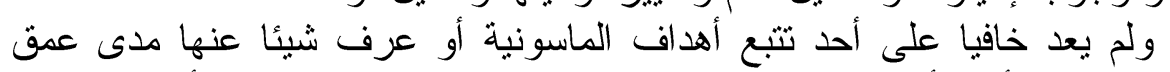

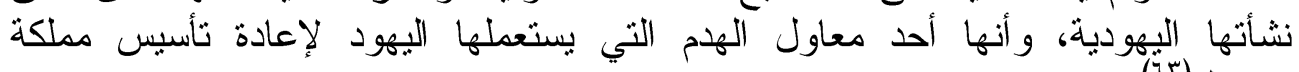

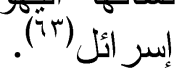

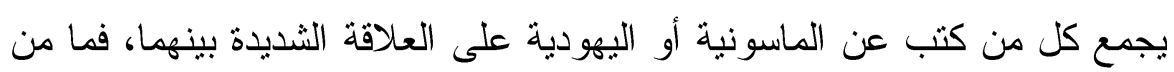

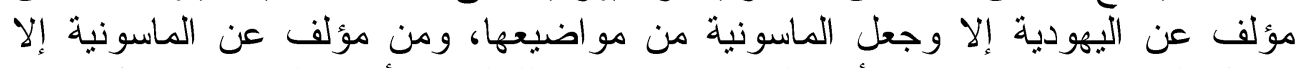

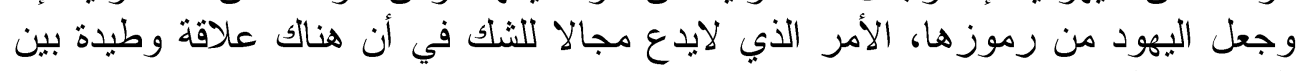
اليهودية و الماسونية.

المبحث الر ابع.

طبقات الماسونية الربع.

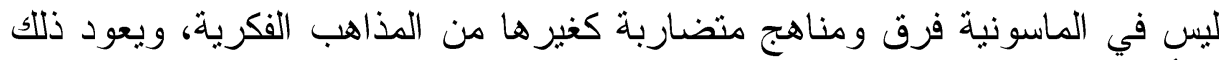

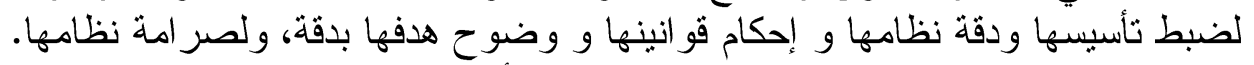

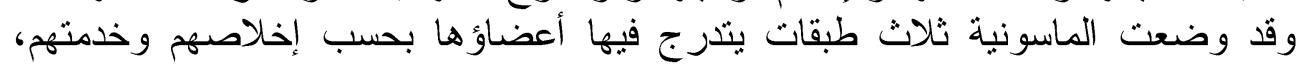

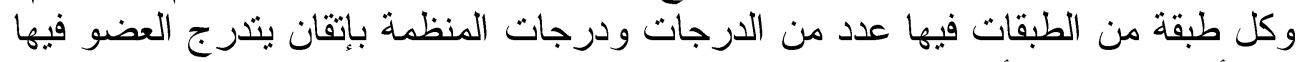

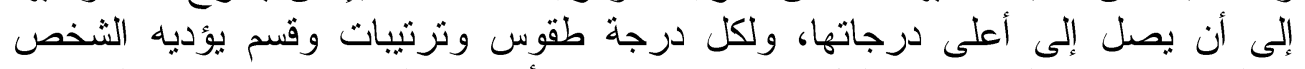

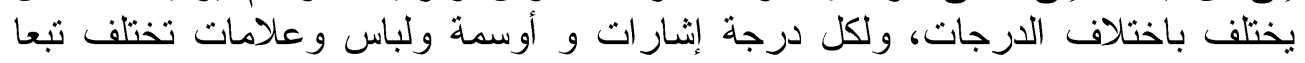
ويمر الداخل في الماسونية بطقوس وتدريبات هائلة قد يفقد اتزان عقله، وقد دخلها

$$
\text { لكل درجة. }
$$

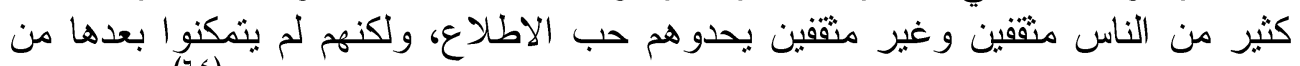

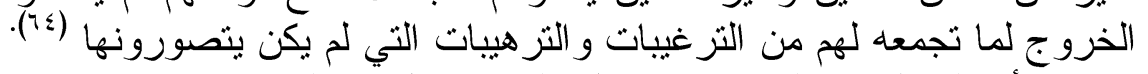

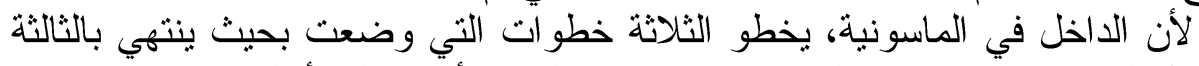

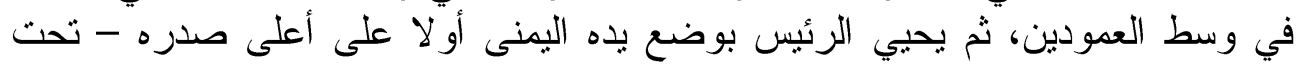

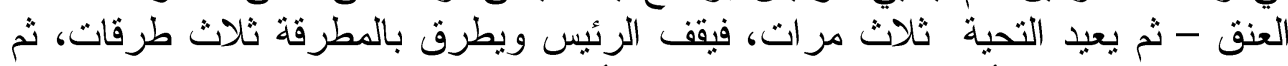

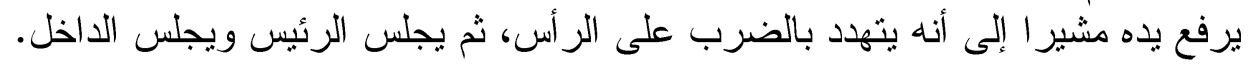


ويتمز الماسونية بهذا الحركات إلى أن الداخل يكرر اليمين التي حلفها عند قبوله

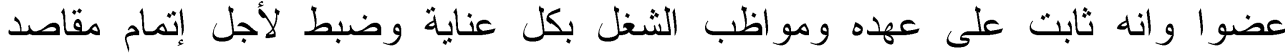
الجمعية، و أنه لاينفأك أمينا ولن يخون، و أما حركة الرئيس فرمز تهديده بالقنل إذا خان النان

وللماسونية ثلاث طبقات ؛ ابتدائية رمزية، و متوسطة ملوكية، وكونية عالية (77)، وفيما يلي تعريف بكل طبقة. الطبقة الأولى وهي الابتدائية الرمزية.

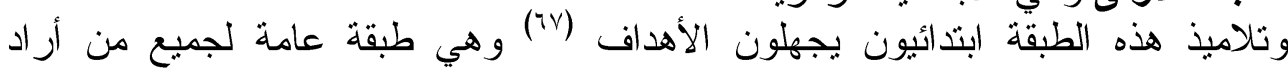
الاخول فيها سواء أكان يهوديا أو من الذي يسمونهم العميان غير اليهود - ويسمون

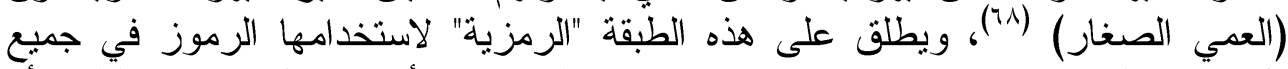

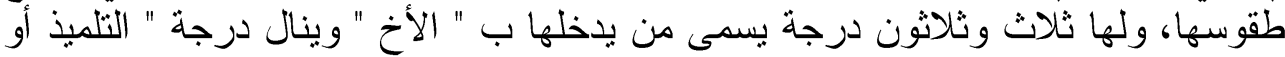

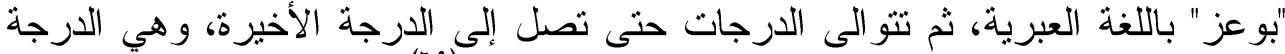

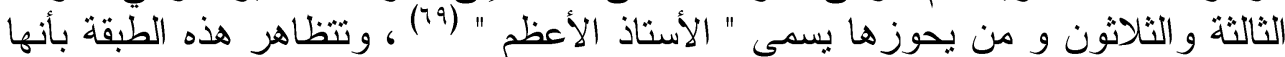

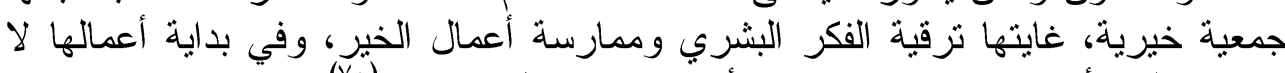

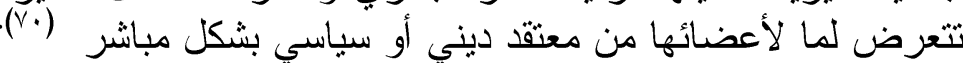
الطبقة الثانية : الماسونية الملوكية.

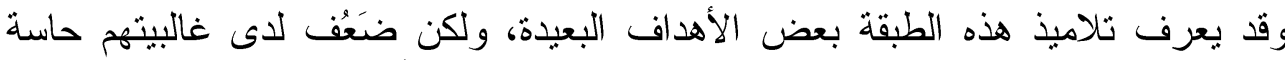

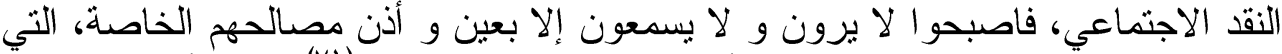

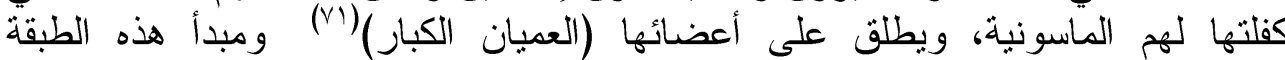

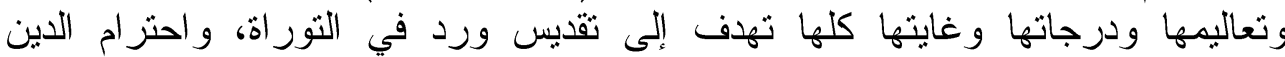

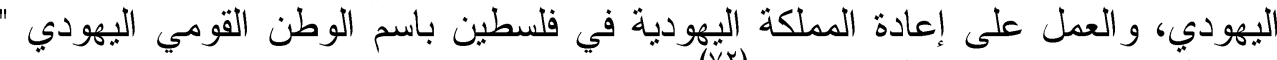

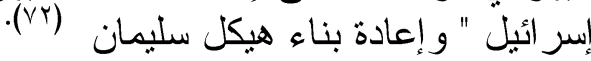

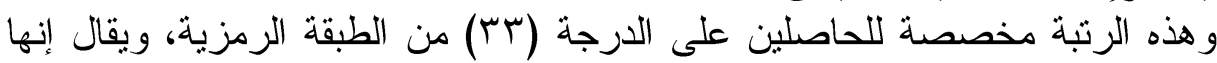

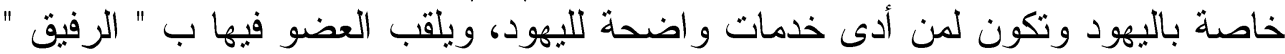

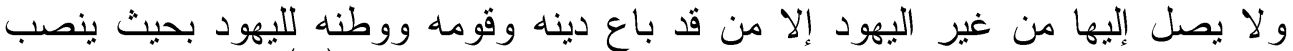

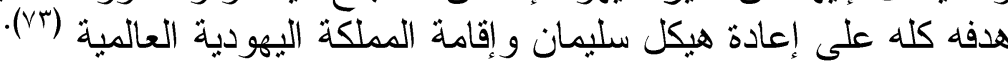
الطبقة الثالثة : الماسونية الكونية العالية.

و تضم هذه الطبقة حكماء إسر ائيل، و ورثة السرة، وهم الذهة الذين بتصرفون بالمحافل عن

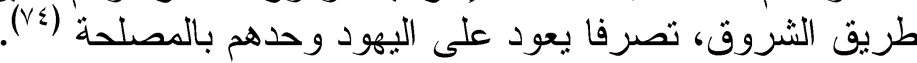

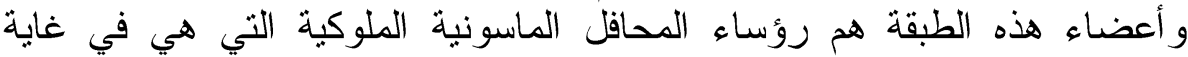

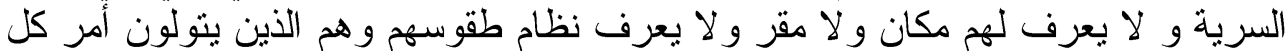

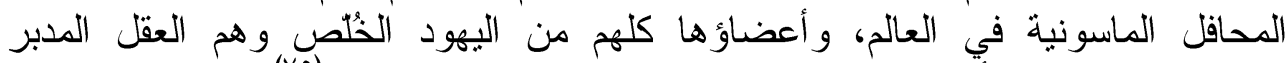

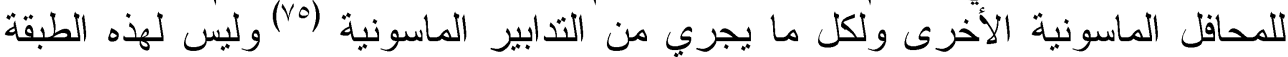

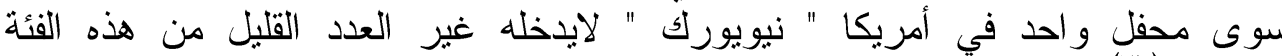
المنفصلة (VT)

و هذه الطبقات الثلاث على تفاوتها في جميع الأمكنة والأزمنة، إلا أنها مثقلة

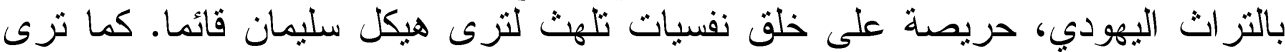

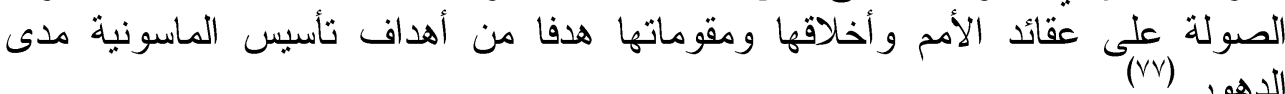




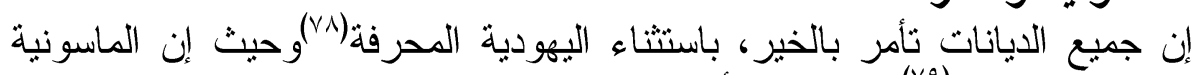
عقائد الماسونية وأفكار ها:

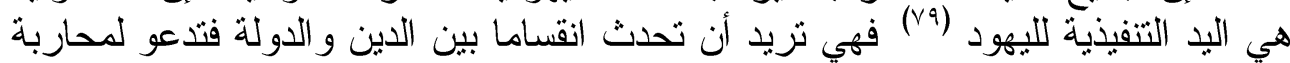

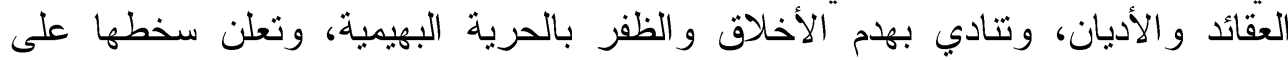

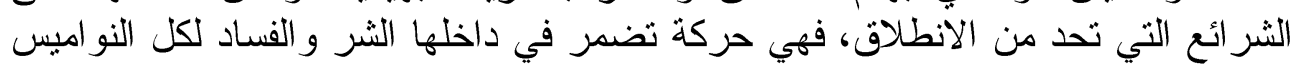

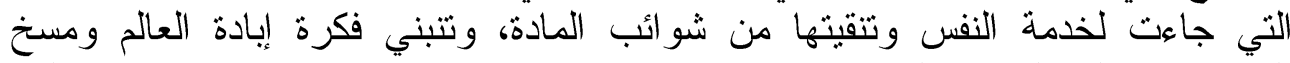

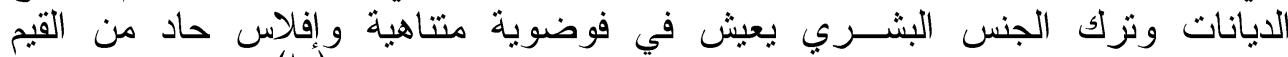

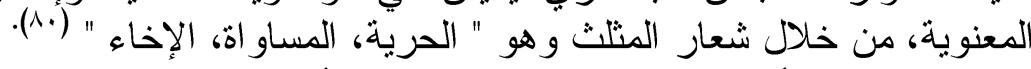

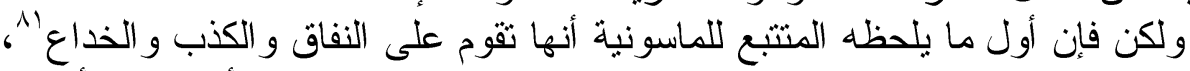

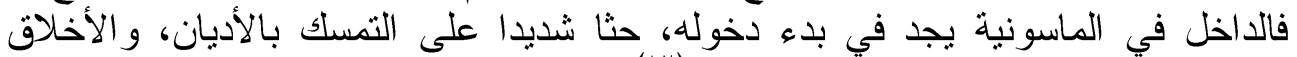

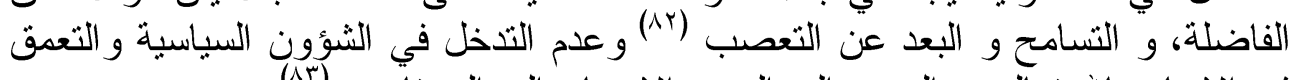

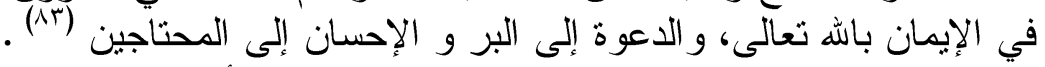

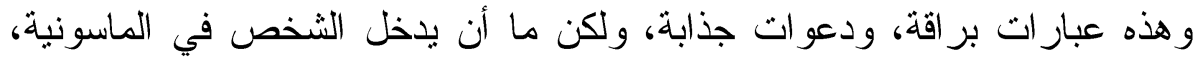

سيجد أن المضمون مختلف تمامأ.

فالأخلاق عند الماسونية تعني أخلاق المعاملات الدنيوية؛ كالصدق و والصبر

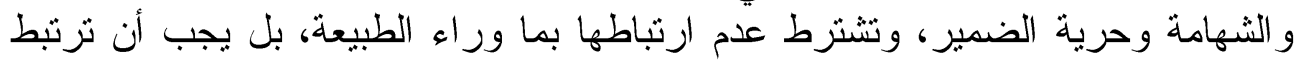

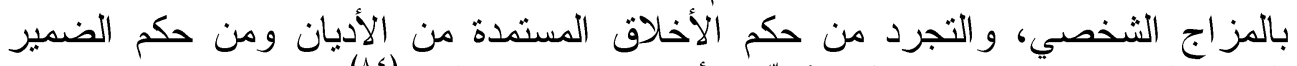

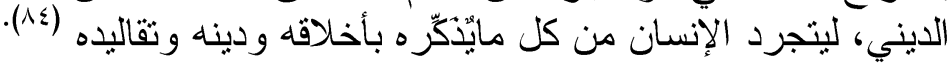

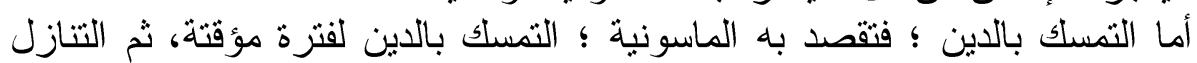

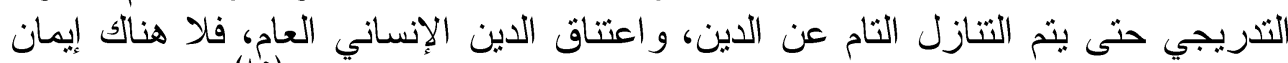

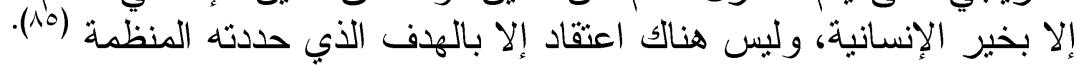

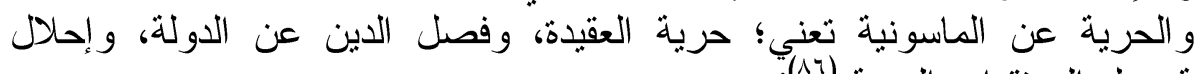

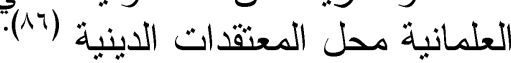
وقد تبنت الماسونية ستة أفكار رئيسة تلخص الأنس مبادئها. الأول : إنكار وجود الله.

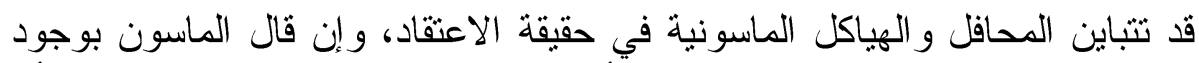

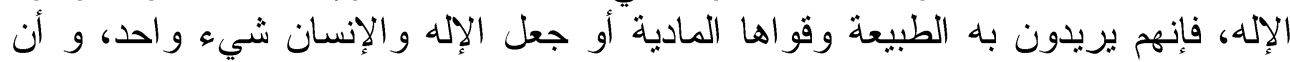

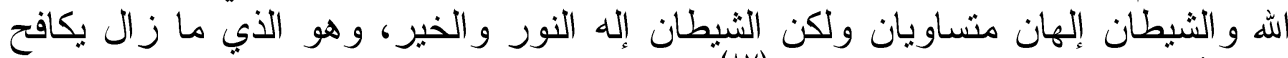

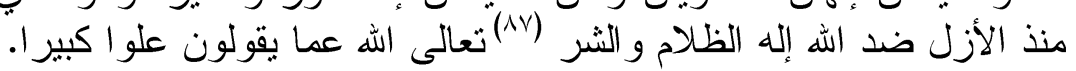

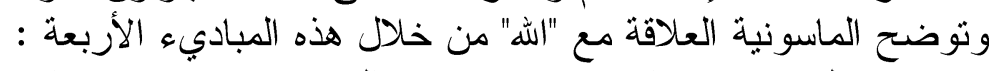

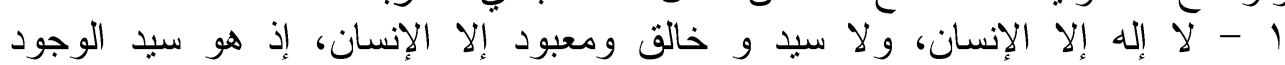
المتصرف بنو اميسه. r - ليس علينا أن نذل أعناقنا لديانات مختلفة، بل علينا أن نتزفع فوق كل إيمان بأي إله

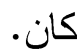
r - علينا أن نسحق القبيح الفظيع و هو ما يدعونه الله.

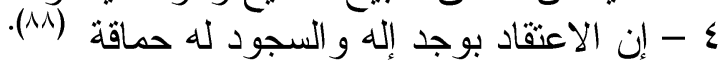


وتؤكد الماسونية على هذا من خلال عقيدتها التي تقوم على أنه لو تم تو السماح

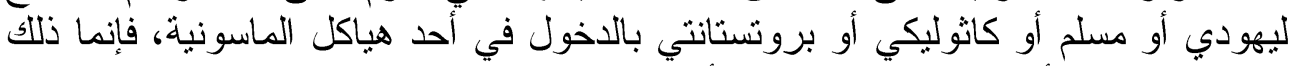

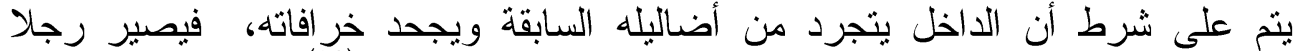

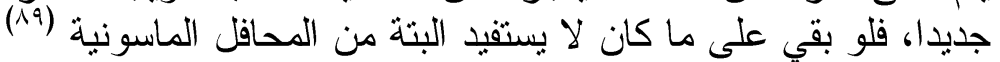

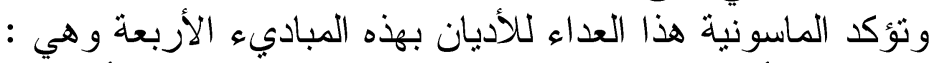

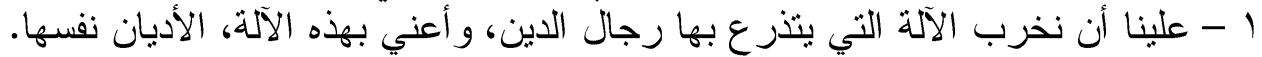

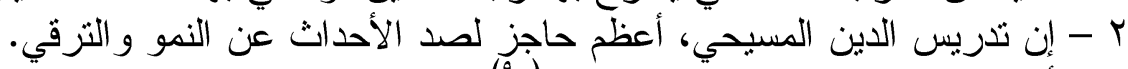

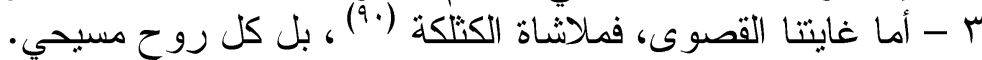

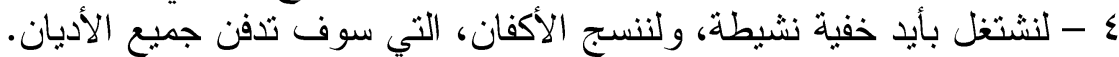

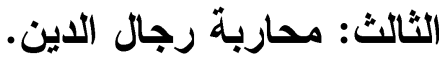
لاتفتأ الماسونية تناصب الأبن الأديان ورجالاتها العداء، و العمل على كسر نفوذهم و هيبتهم و إبادتهم من الوجود.

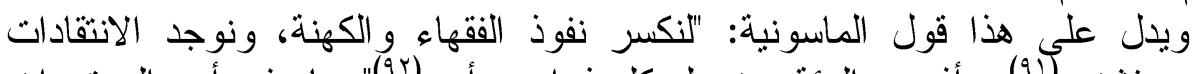

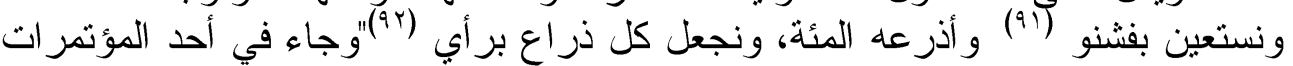
الماسونبة العالمية قولهم: "إننا لا نكتفي بالانتصار على المتدينين ومعابدهم إنما غايتتا

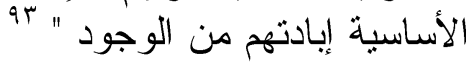

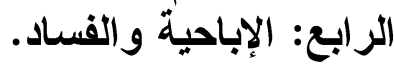

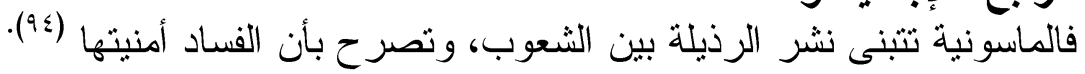

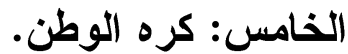

فالماسونية تقوم على رذه الوطن الأوطان ليقيمو ا على أنقاضها وطنهم (90) السـادس: هالمو البشرية. فالماسونية تزى البثرية أنه كل شيء يجوز لهم، ومن ينكر مبادئهم يجوز استئصاله،

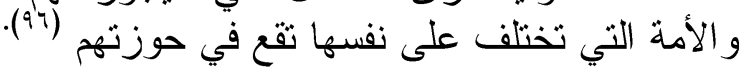
و لا "غرابة في كل ماسبق إذا علمنا بأن الماسونية تستمد فكرها من التلمود وهو

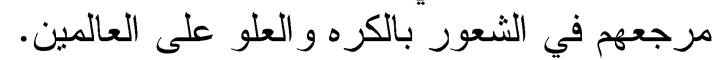

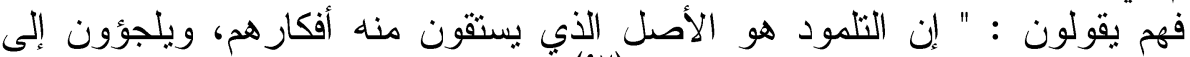

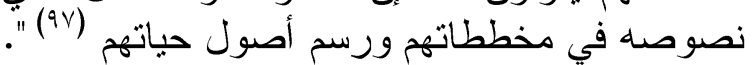

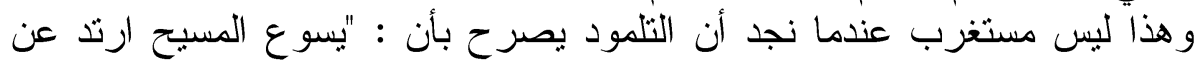

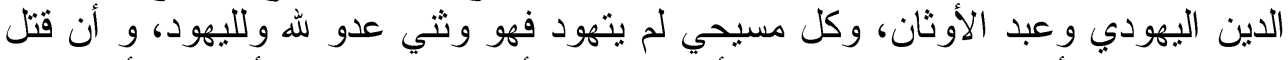

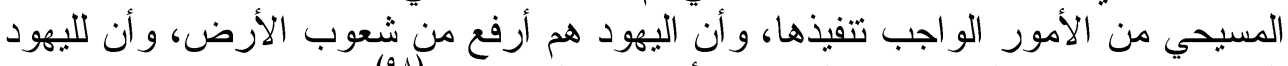

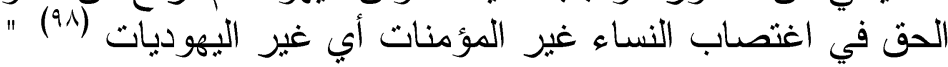
المباسونية السادس. المعاصرة.

نبين لنا مما سبق عند الحديثة الحديث عن نشأت الماسونية، أن تحديد تاريخ دقيق لنشأتها

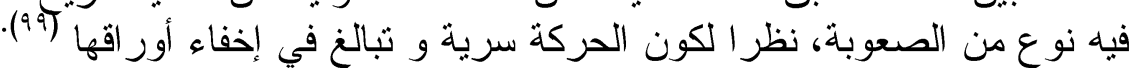

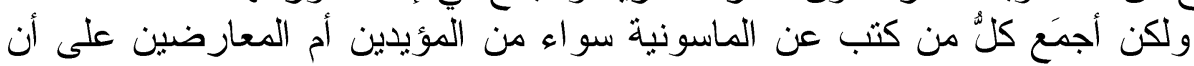

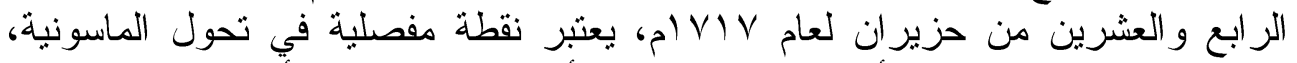

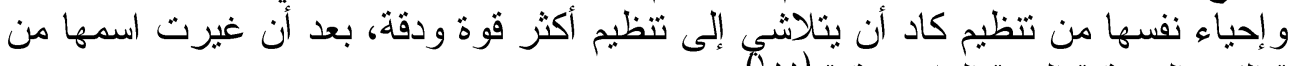

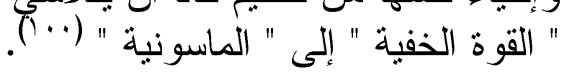




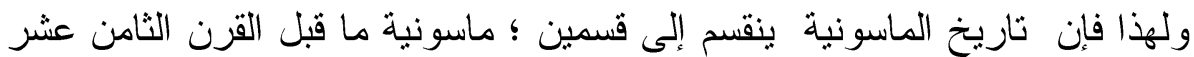

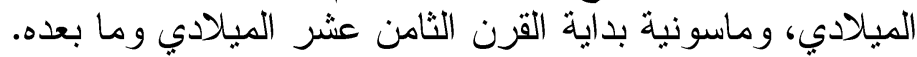

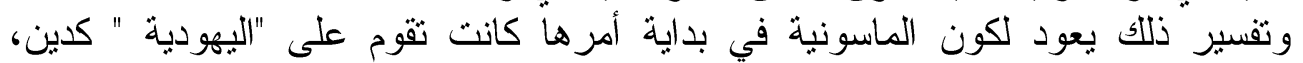

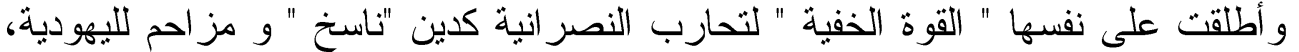

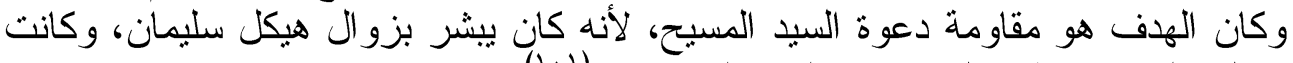

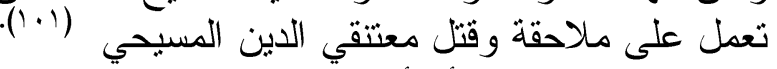

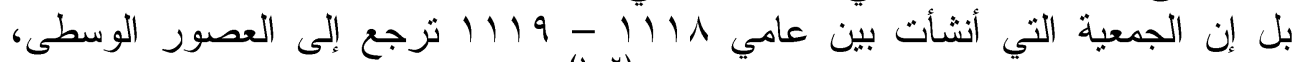

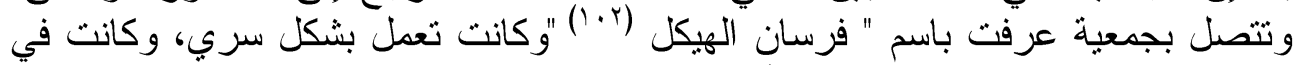

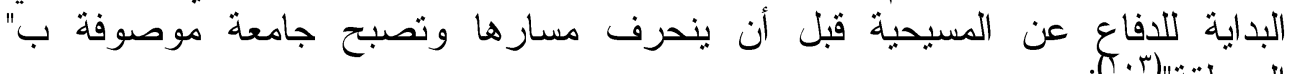

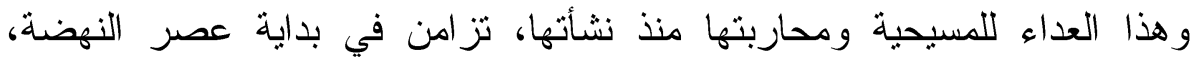

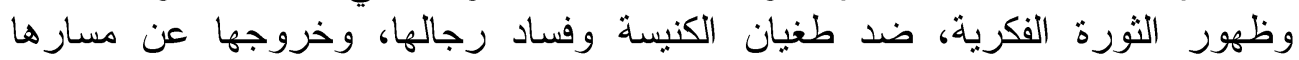

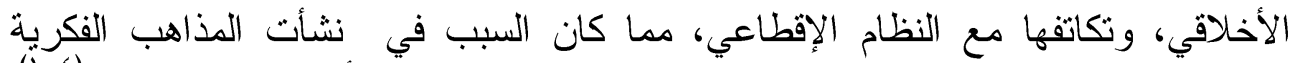

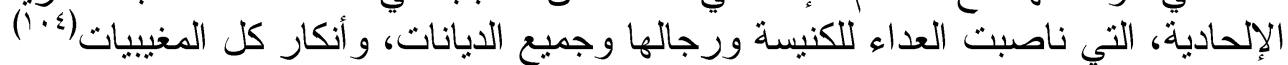

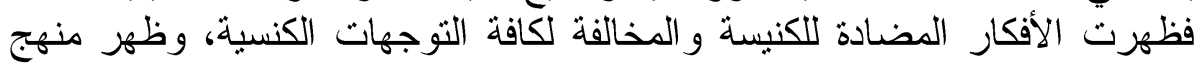

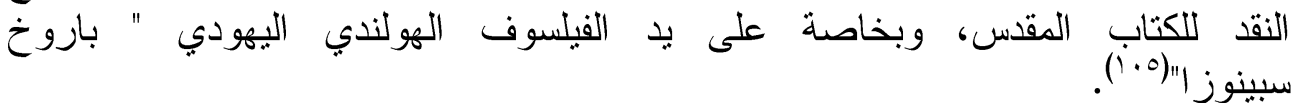

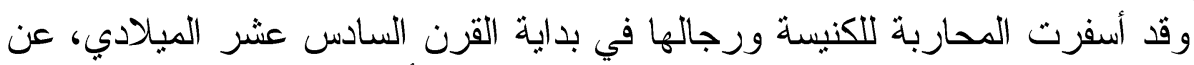

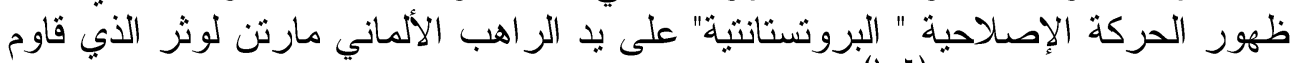

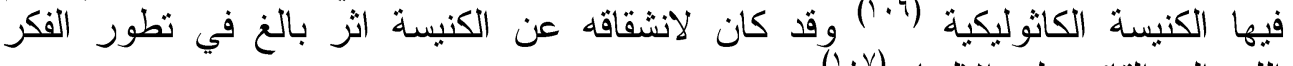

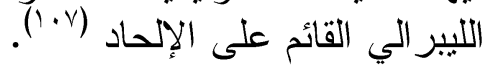

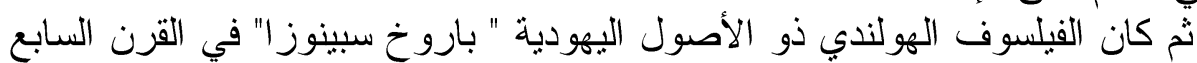

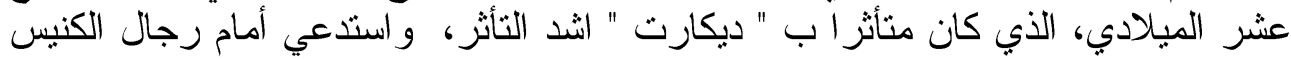

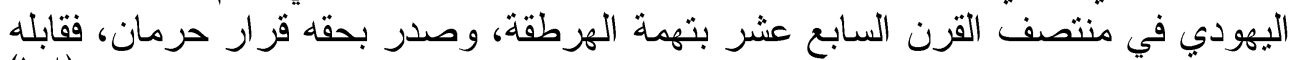

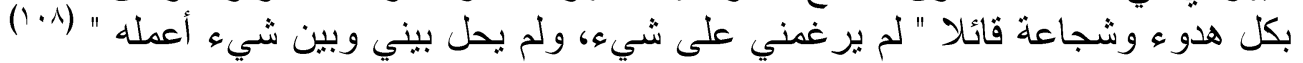

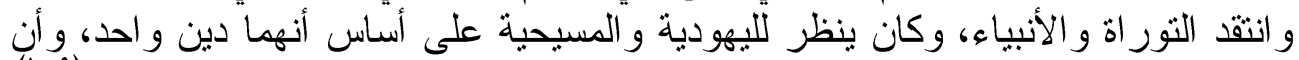

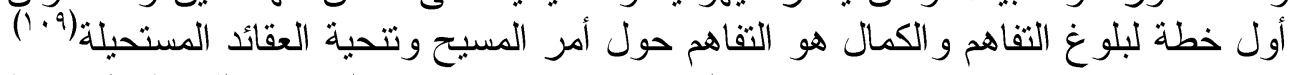

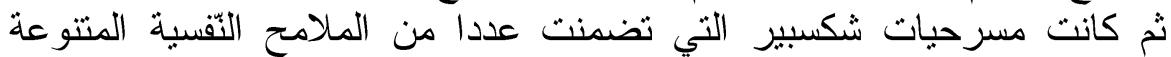

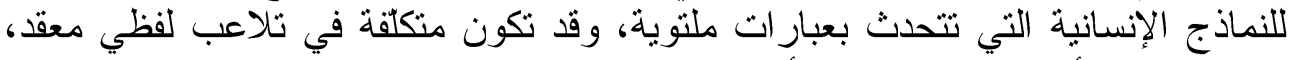

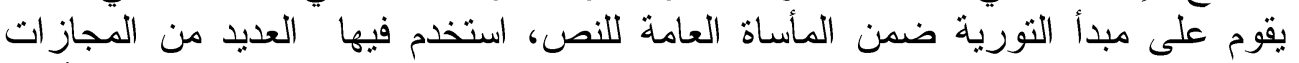

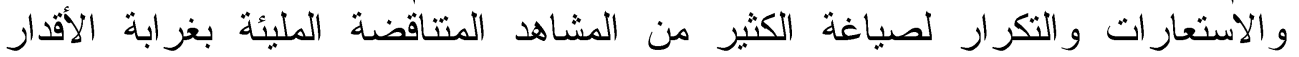

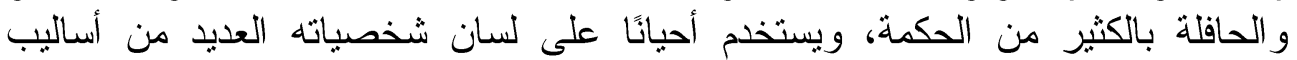
(السخرية و التفاهات المفعمة بالمرح الصاخب لتصب في قالب الانقلاب على الفكر الديني

ثم ظهر فولتير في بداية القرن الثامن عشر المبلادي، الذي كان بهاجم الكنبسة بكل

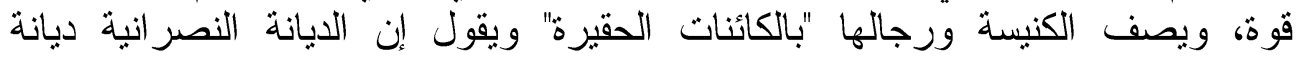

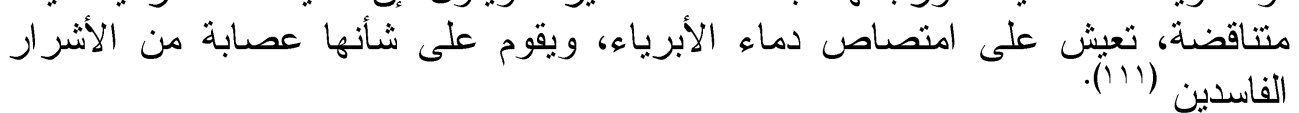




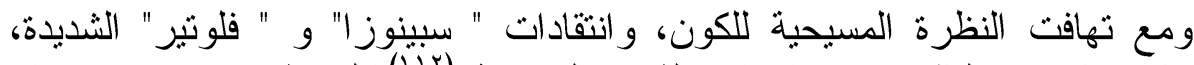

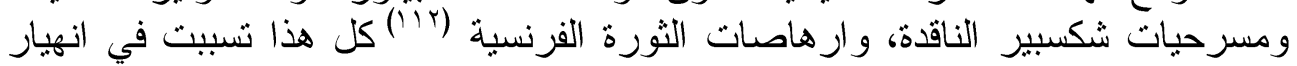

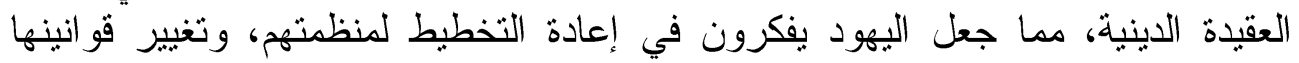

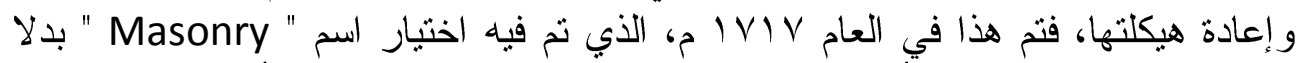

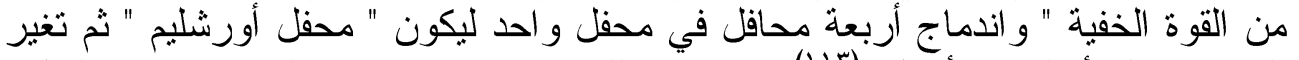

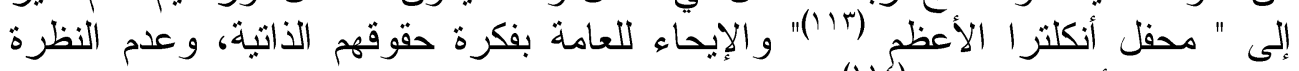
للملو ك على أنهم إر ادة الله (1) (1).

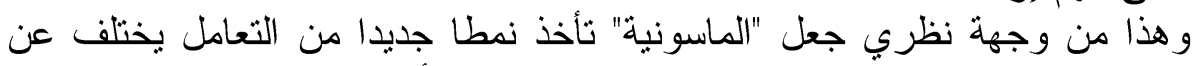

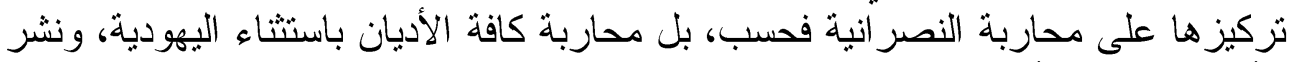

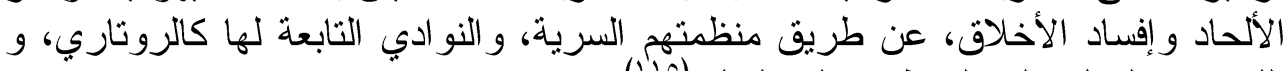

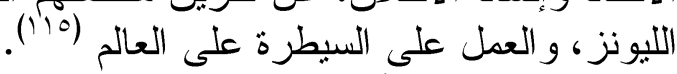

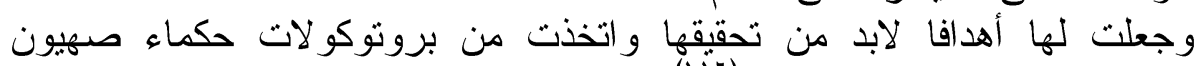

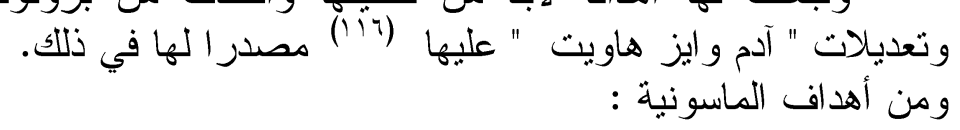

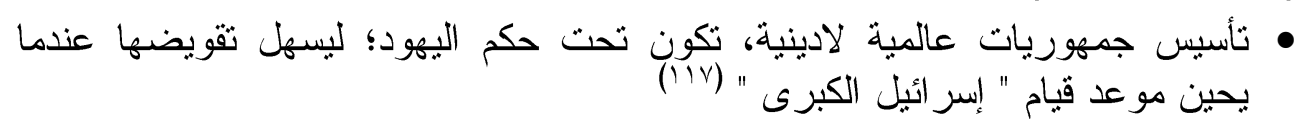

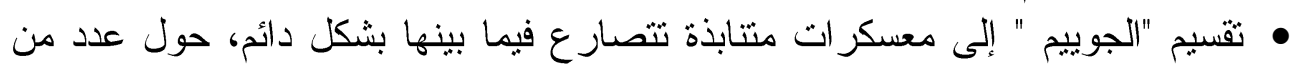

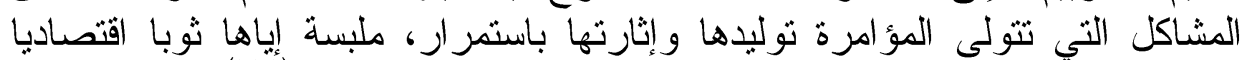

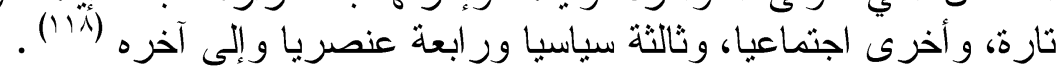

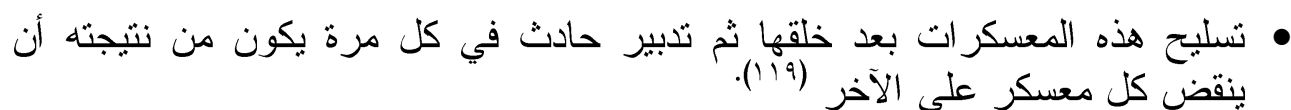

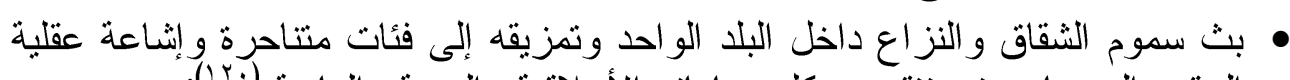

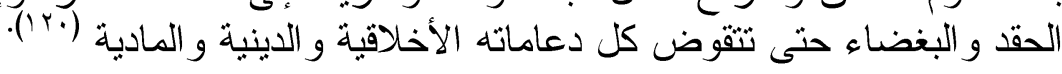

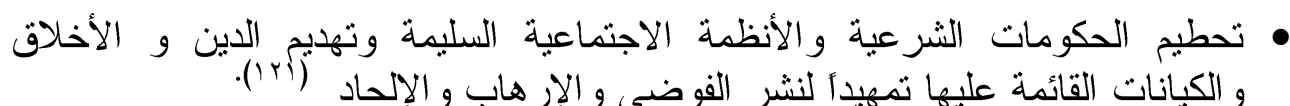

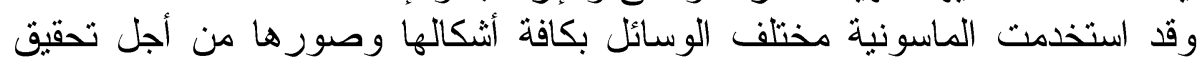
تعود (أهوبr). جاعلة "بروتوكولات حكماء صهيون" نصب عينبها مرجعا لها منه تتهل و إليه

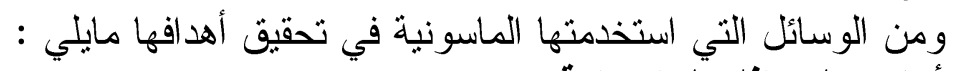
أولا : المحافل الماسونية.

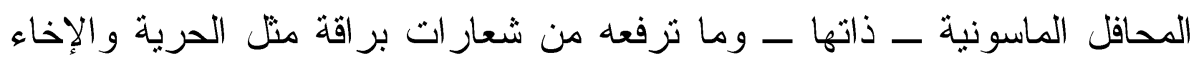

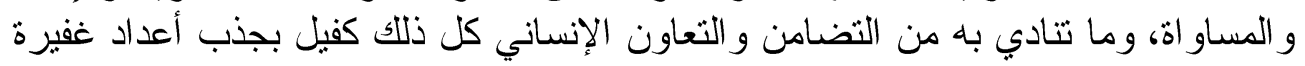

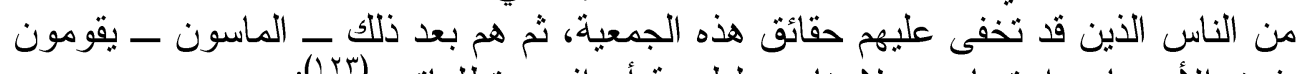

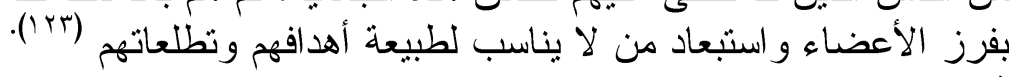
ثناتيا : الرشوة.

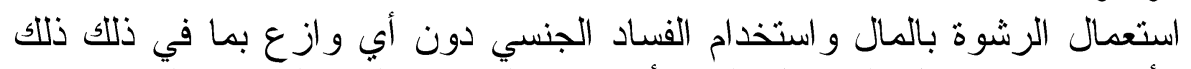

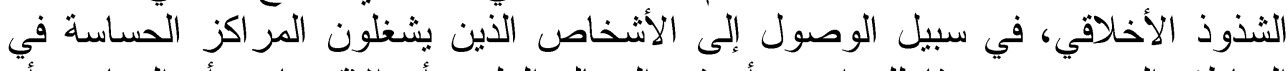

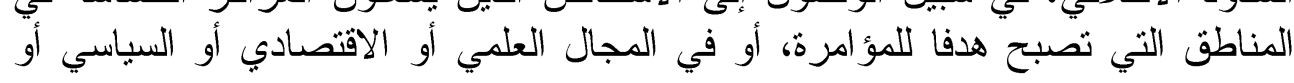


الاجتماعي أو غبره ، ثم جعل من يقعون في الفخ، مرتهنون لتلك العلاقات المشبوهة،

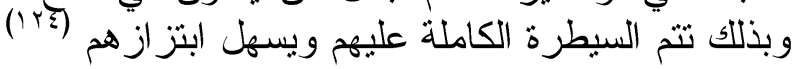

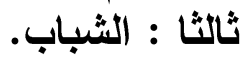

اهتمت الماسونية بفئة الثباب ولذلك تحرص على أن يهنغ الأساتذة "النو اريون(ro(l)"

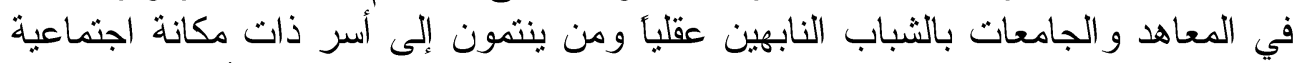

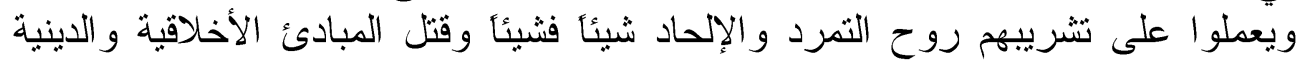
و الوطنية في نفوسهم وغرس عقلية الاستهتار بتلك القيم و المثل العليا في عقولهي الهم وفكر هم.

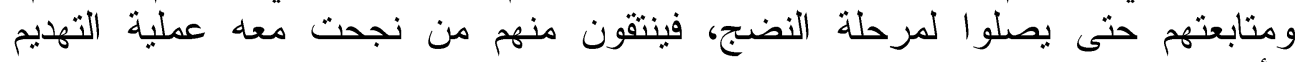

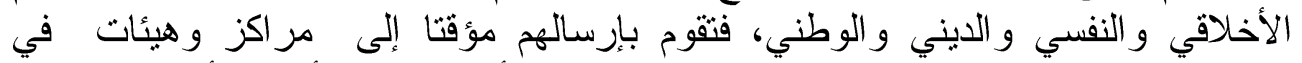

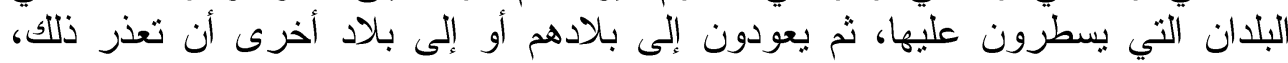

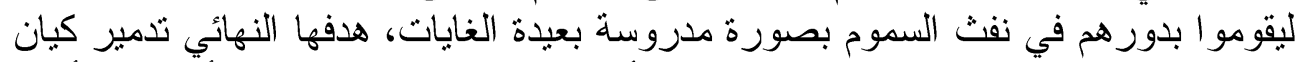

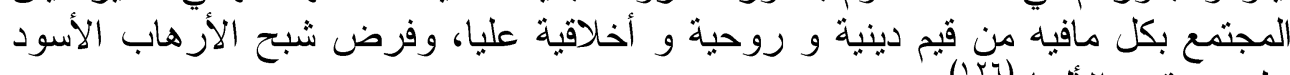

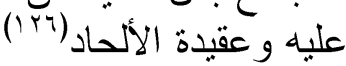

رابعا : الإعلام

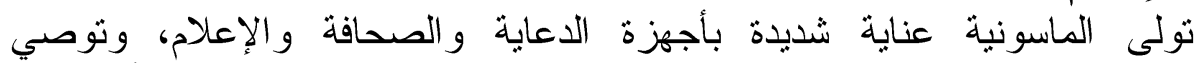

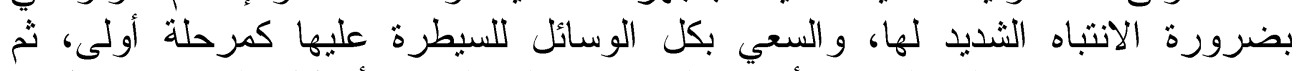

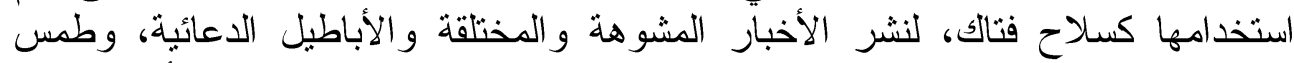

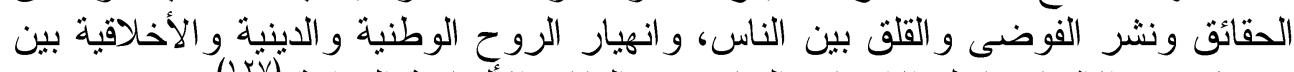

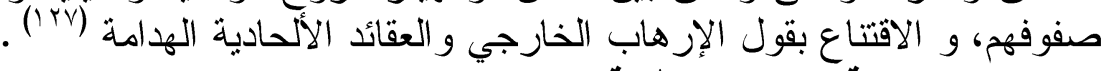

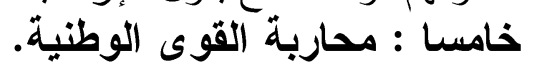
تقوم الماسونبة على محاربة كل القوى القوى الاجتماعية أو الو الوطنية التي تسعى إلى الخبر

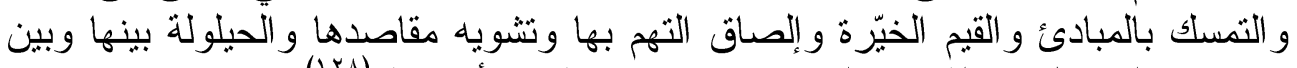

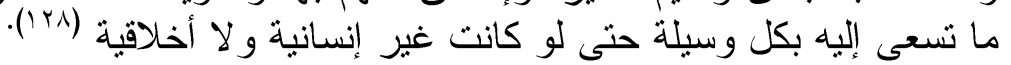
سادسا : التجسس.

تعمل الماسونية من خلال محافلها و أعضائها كأجزة استخبار ات سرية للتجسس التهاء

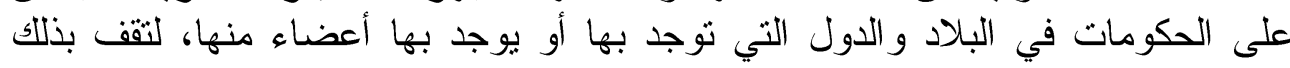

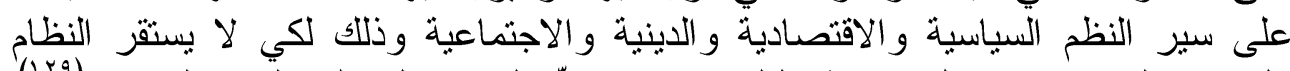

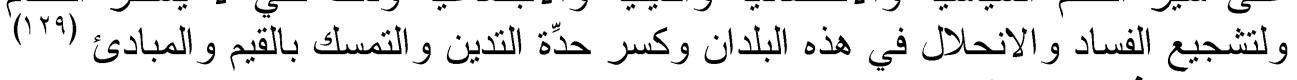
سابعا : أفساد الاخلاق.

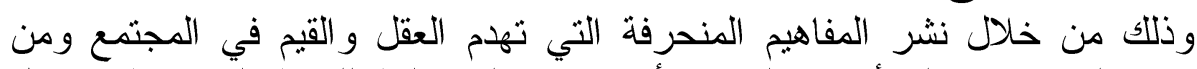

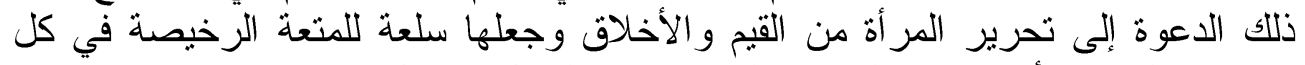

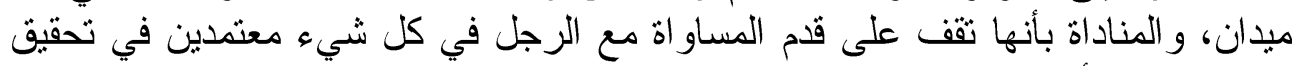

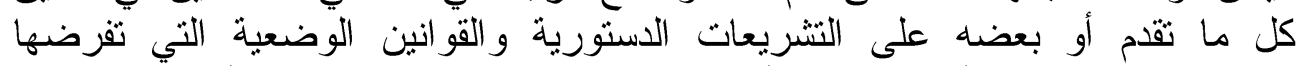

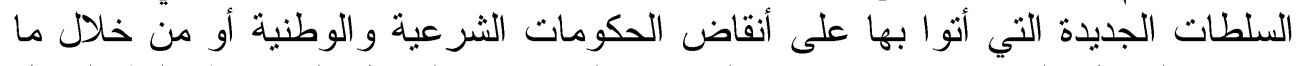

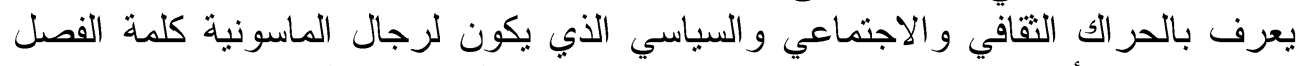

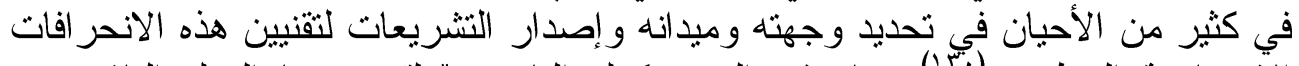

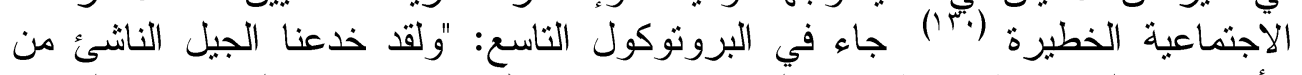

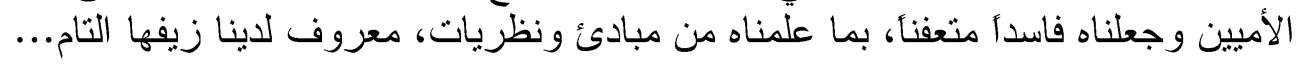




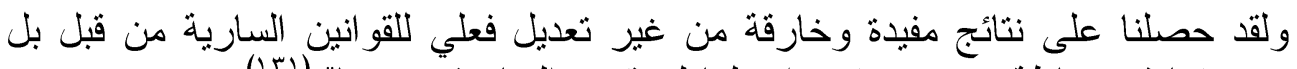

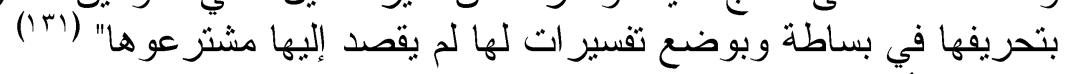
ثامنا : الأرهاب.

ثقوم الماسونية بعمليات الاغتيال للتخلص من كل من يقف في طريقها ولم ينجح

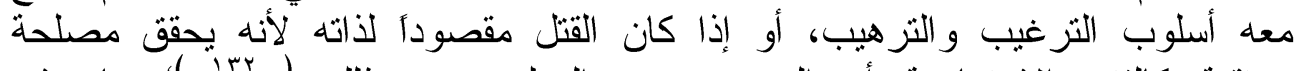

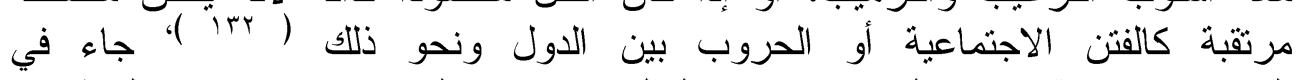

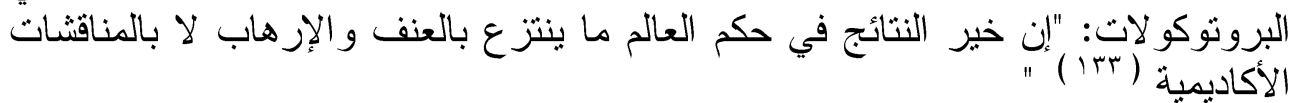

تاسعا : العلمانية.

و هذا يعد من أعظم وسائل الماسونية لتحقيق أهدافها وتمكين اليهود في فلسطين

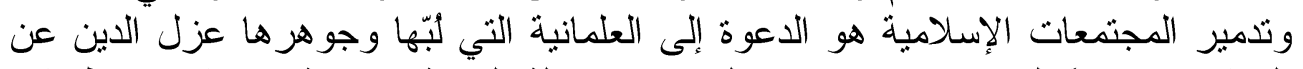

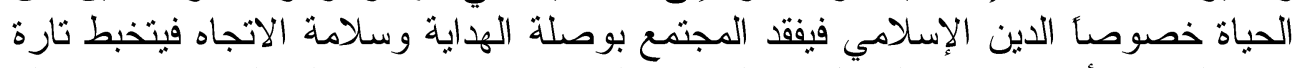

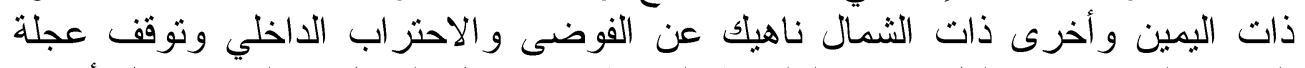

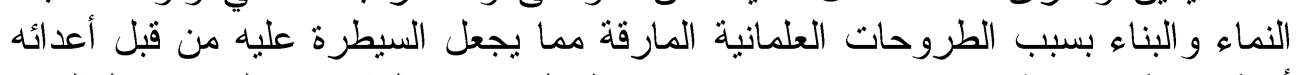

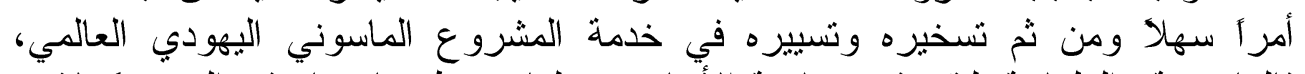

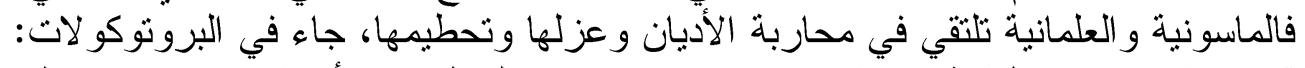

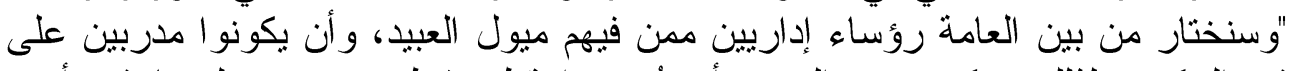

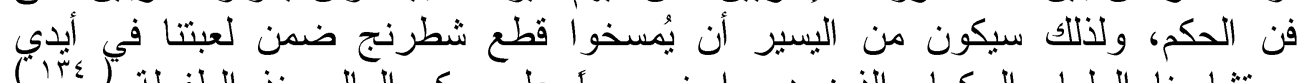

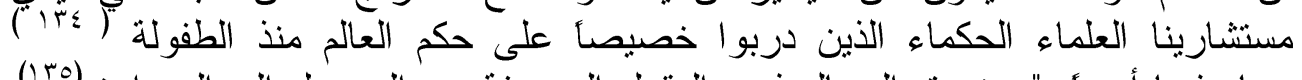

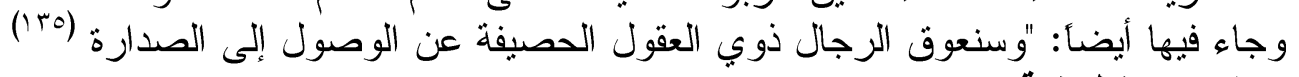
عاشر ا : الطائفية.

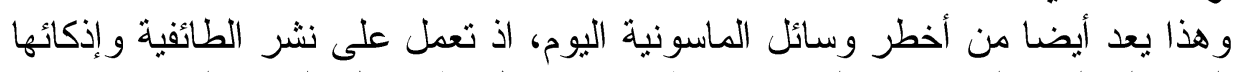

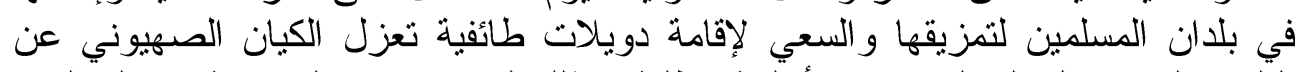

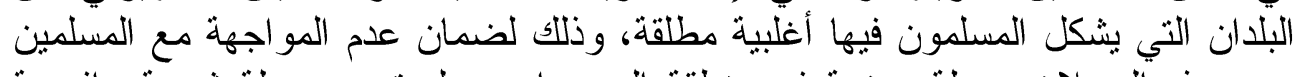

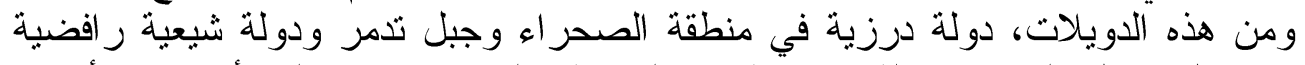

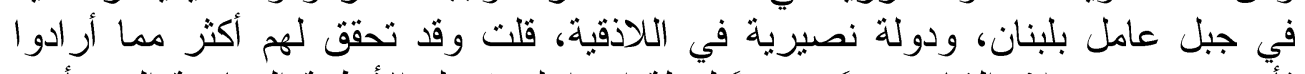

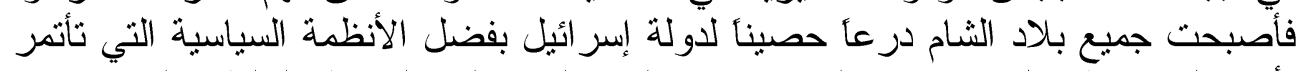

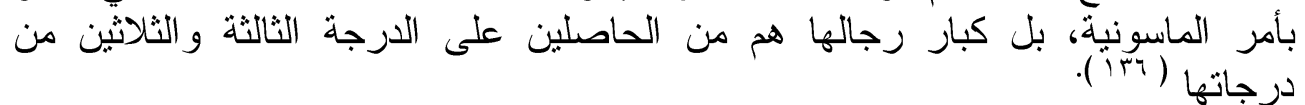

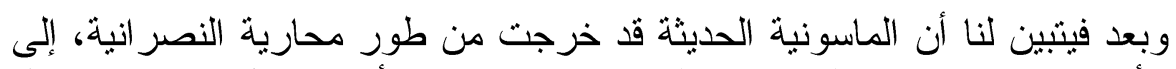

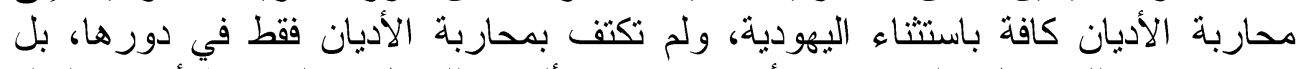

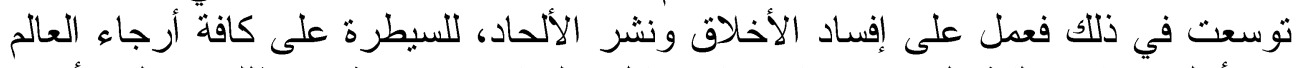

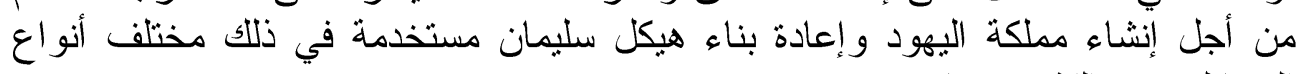

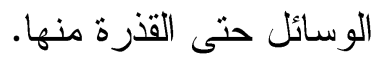

\section{موقف الإسلام من الماسونية والإتماء إليها.}

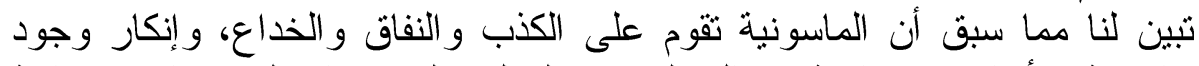

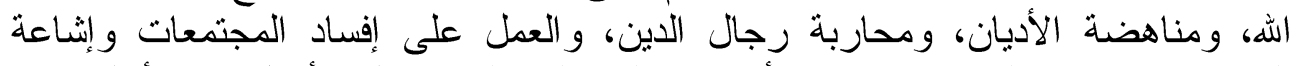
الفوضى، وتجريد المجتمعات من الأخلاق والقيم الفاضلة، ورذل الألهان الأوطان من أجل إقامة 
وطنهم على أنقاض ذللك، مستخدمة في ذلك كافة الوسائل و الأساليب مهما بلغت درجة حقارتها.

وكل و احد مما سبق بعتبر " طامة " لوحده، وخيانة للاين و الوطن و الإنسانية.

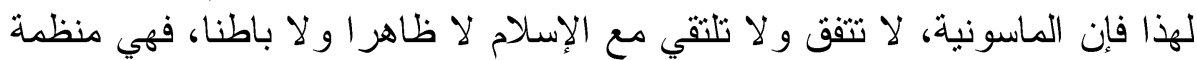

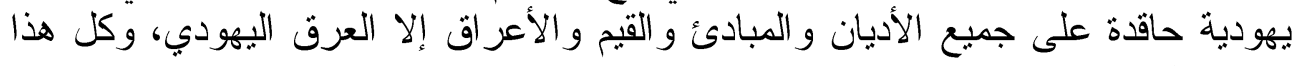
لا يرضاه الإسلام.

وقد صدرت العديد من الفتاوى تبين حكم الإسلام في الماسونية ومن تلك الفتاوى ؛

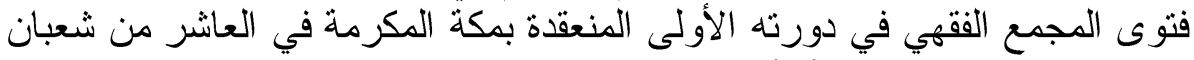

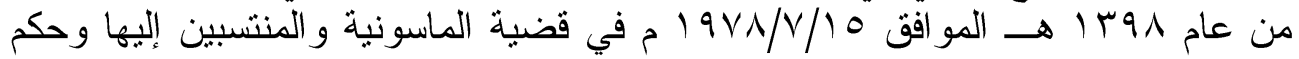

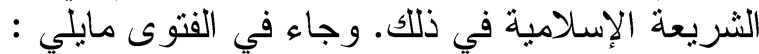
الحمد لله، و الصدلاة و السلام على رسول الله و على آله و وأصحابه ومن اهتدى بهداه،

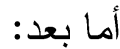
نظر المجمع الفقهي بدورته الأولى المنعقدة في مكة المكرمة في العاثر من شعبان

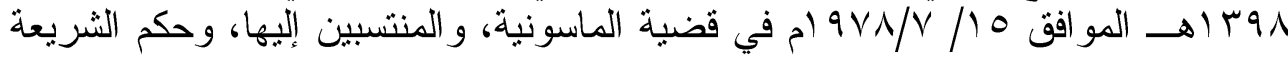
الإسلامية في ذلك.

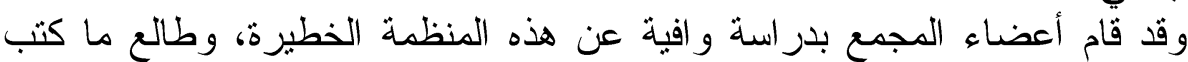

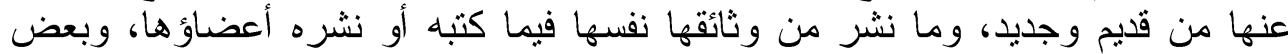

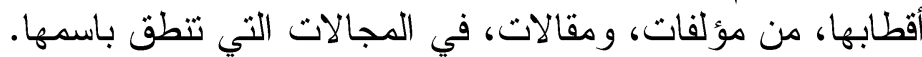

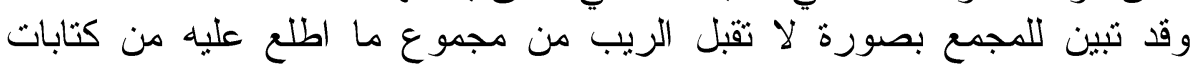
ونصوص ما يلي: الين 1- أن الماسونيةّة منظمة سرية تخفي تنظيمها تارة، وتعلنه تارة بحسب ظروف الزمان

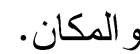
ولكن مبادئها الحقيقية التي تقوم عليها هي سرية في جميع الأحوال، محجوب علمها حتى بلى التئ

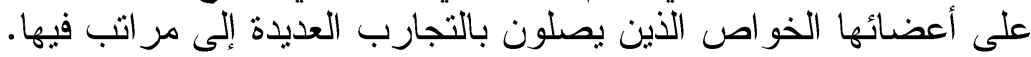

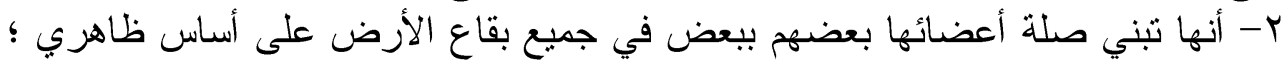

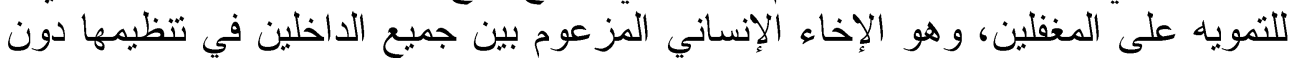

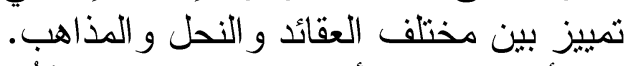

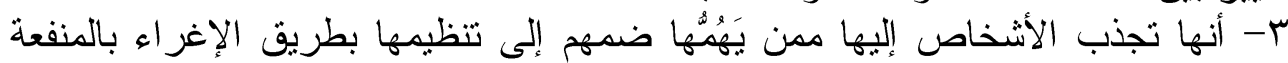

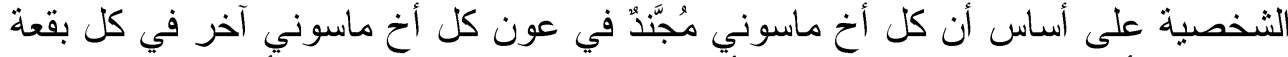

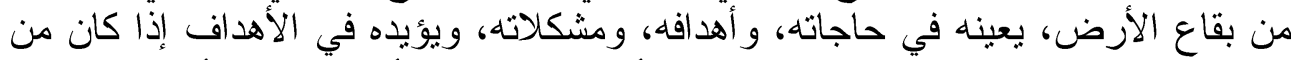

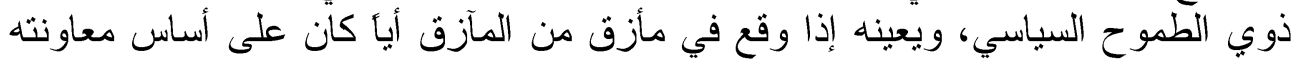

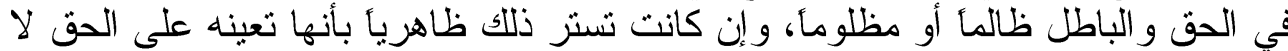
الباطل. و هذا أعظم إغراء تصطاد به الناس من مختلف المراكز الاجتماعية، وتأخذ منهر

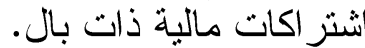
ع- أن الدخول فيها يقوم على أساس احتفال بانتساب عضو جديد تحت مراسم وأشكال

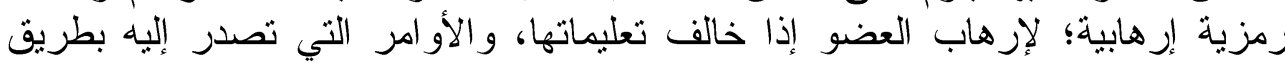




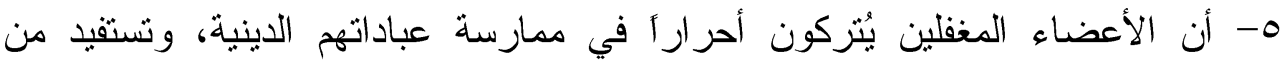

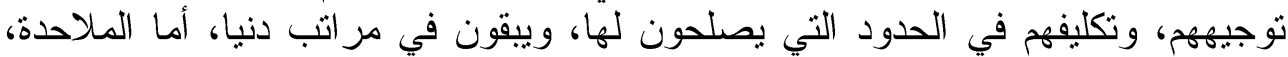

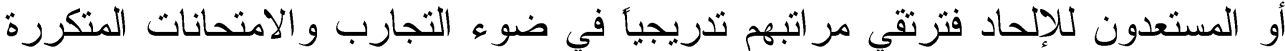

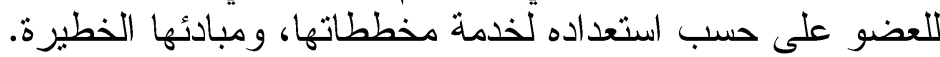

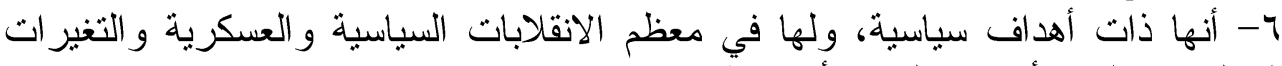
الخطيرة ضلع، و أصابع ظاهرة أو خفية.

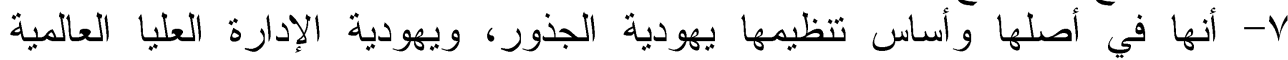
السرية، وصهيونية النشاط. ᄉ- أنها في أهدافها الحقيقية السرية ضد الأديان جميعا؛ لتهديمها بصورة عامة، وتهديم

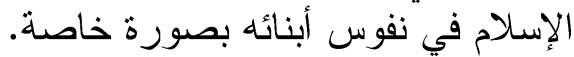

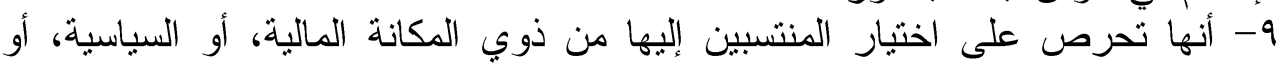

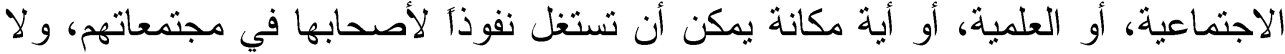

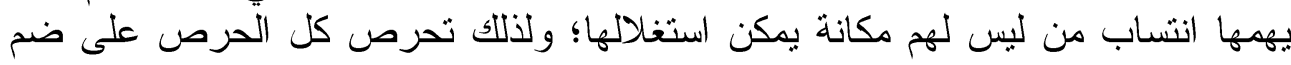

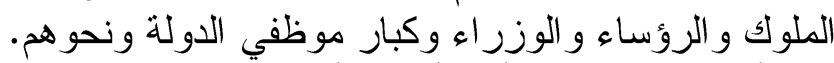

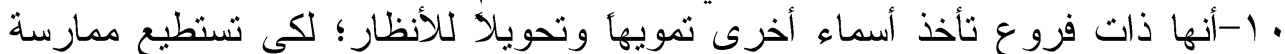

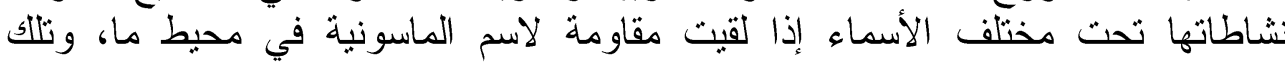

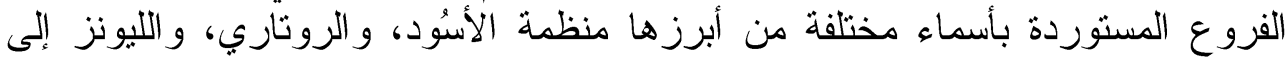

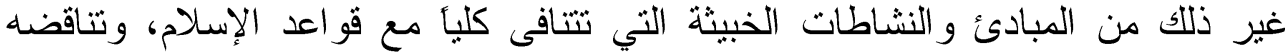

وقد تبين للمجمع بصورة واضحة العلاقة الوثيقة للماسونية باليهودية الصهيونية مناقضة كلية. - مليز

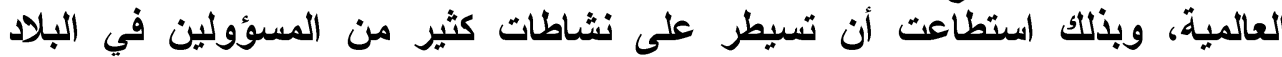

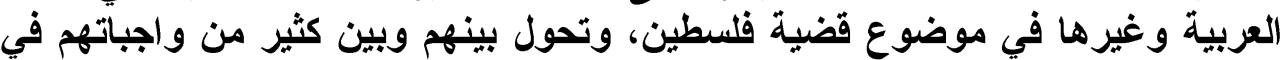

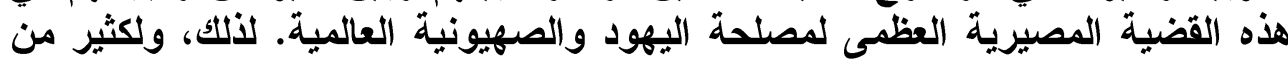
المعلومات الأخرى التفصيلية عن نشاط الماسونية، وخطورتها العظمى، وتلبيساتها الخبيثة، وأهدافها الماكرة.

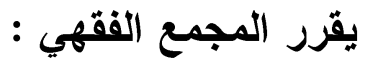

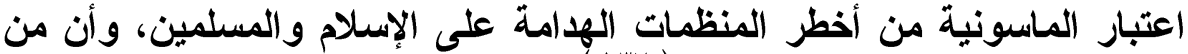

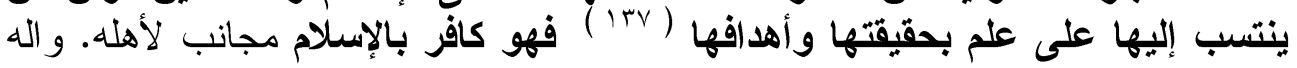

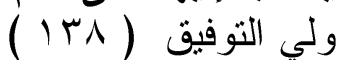
كما أصدرت لجنة الفتوى بالأزهر بيانأ بشأن الماسونية والأندية التابعة لها مثل الليونز و الروتاري جاء فيه:

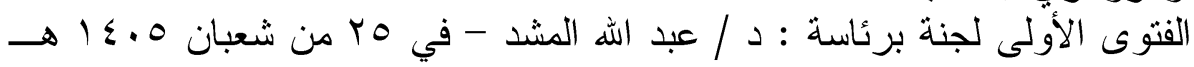

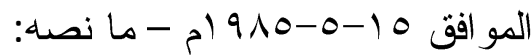

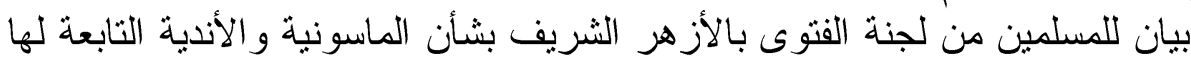

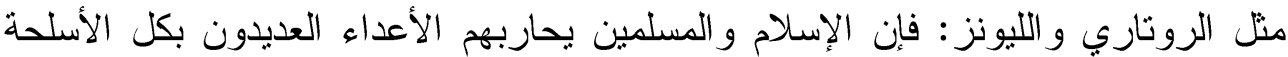

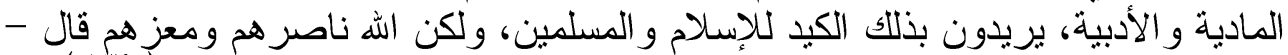

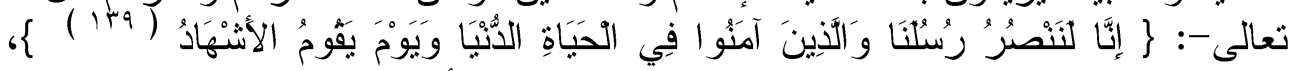

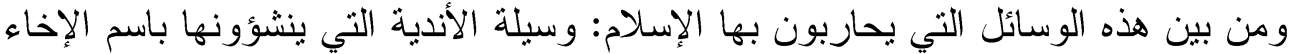
و الإنسانية، ولهم غاياتهم و أهدافهم الخفية ور اء ذاء ذلك، و إن من بين هذه الأن الأندية الماسونية

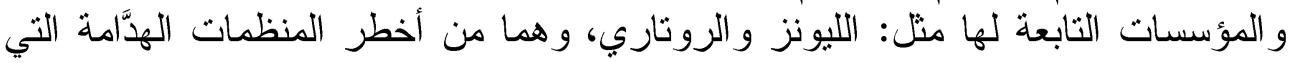




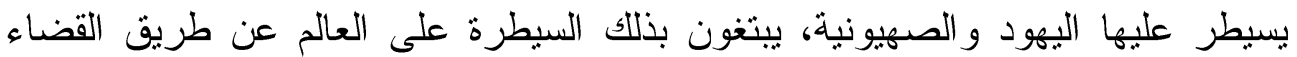

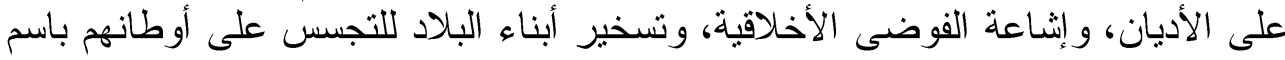

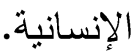

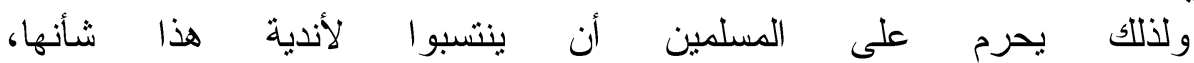

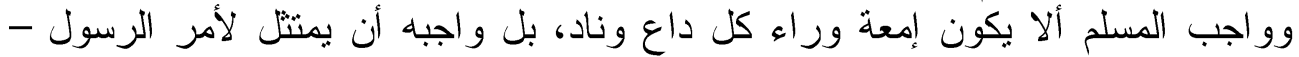

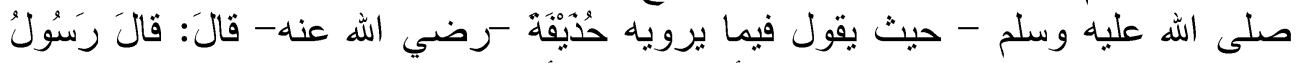

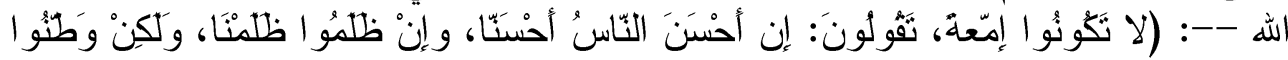

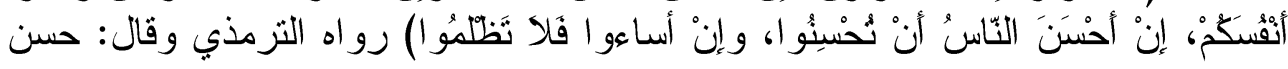

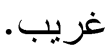

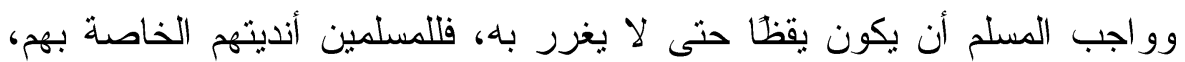
و التي لها مقاصدها وغاياتها العلنية، فلبس في الإسلام ما نخشاه و لا ما نخفيه.... و الله

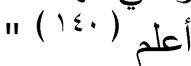

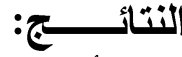
وهنا أبرز ما تحصل من نتائج.

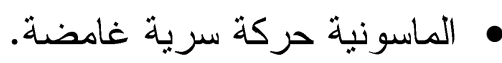
• صعوبة تحديد ثاريخ دقيق لنشأة الماسونية بالمفهوم الحديث قبل القرن الثامن عشر

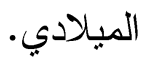
• سبب اختيار لفظ " masons " للتمويه و الخداع وتمرير المخططات بسبب وجود

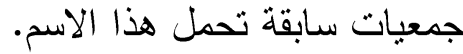
• كان الاسم السابق هو " القوة الخفية " ولكن لكونه يكاد يموت، تم استبداله ب "

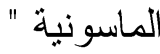
• أول اجتماع لتعديل الاسم وتغيير القو انين الخاصة بها ن كان من قبل يهود.

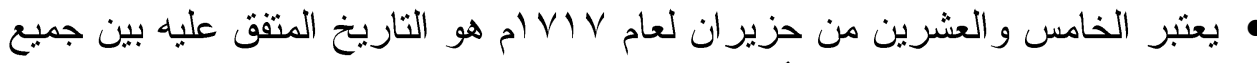

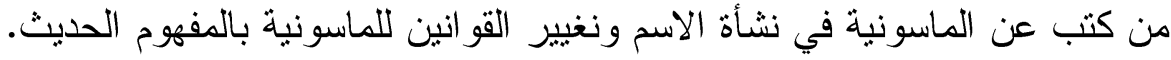

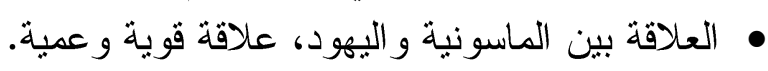

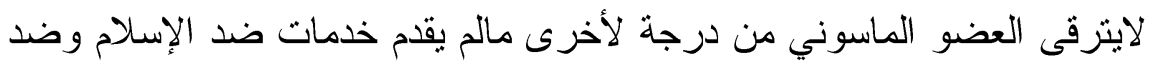

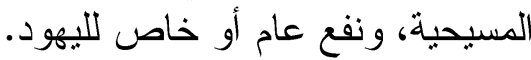

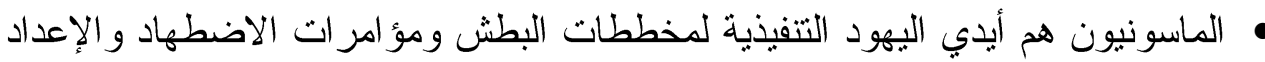

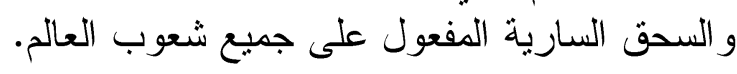

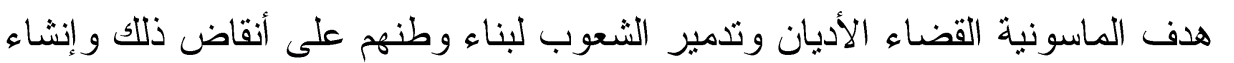
مملكة اليهود و إعادة بناء هيكل سليمان. المباب يعتبر فريسة جيدة للماسونية.

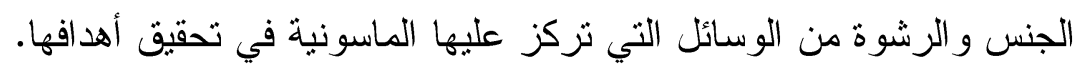
• حرمة الانتساب لهذه الجمعية أو لأنديتها. هذا وصلى الله على نبينا محمد وعلى آله وصحبه وسلم. 


\section{Abstract \\ Mason presentation and discussion \\ By Mansour bin abdulaziz al-hajhili}

The search contained an introduction, a preface, and seven searches; the preface presented the search plan, method, and importance; the preface entered the search, and a confidential statement of this movement. Then the first researcher was on the definition of freemasonry, where the verbal definition was given, and that the term "freemasonry" was made up of three syllables, she; Lastly, it has been called "mason", meaning trade or construction, and "ry", which is not restricted to anyone; lastly, it has been called "mason" in $1 \mathrm{~V} / \mathrm{V}$; then it has been called "mason" instead of the old name "hidden power" and it has chosen "mason" as a symbol for the builder who will build the structure of Solomon. The idea was to identify the masonic as an organization, speak out for supporters and opponents, and conclude that the masonic "was a destructive ideology, one of the most dangerous movements created by the hateful jewish mentality to hold the world together and rule it according to jews' will, with the aim of preserving the jewish human being, enabling him to control the course of human societies, free from the controls of belief in god, and all of its heritage in religious belief, and to prepare the ground for a long and far-reaching battle against Islam and its people in different homelands. The second was the progeny of the masons, whose progeny was difficult to trace, since the organization was secretive and concealed its papers excessively. I presented the statement in this, and divided it in two, before the eighteenth century and after the early eighteenth century, and I surmised that a freemason in the modern sense originated after the eighteenth century A.D. IVIV. The third search was for a masonic relationship with the jews, in which it was shown that the masons were a purely jewish innovation, and that the masons were

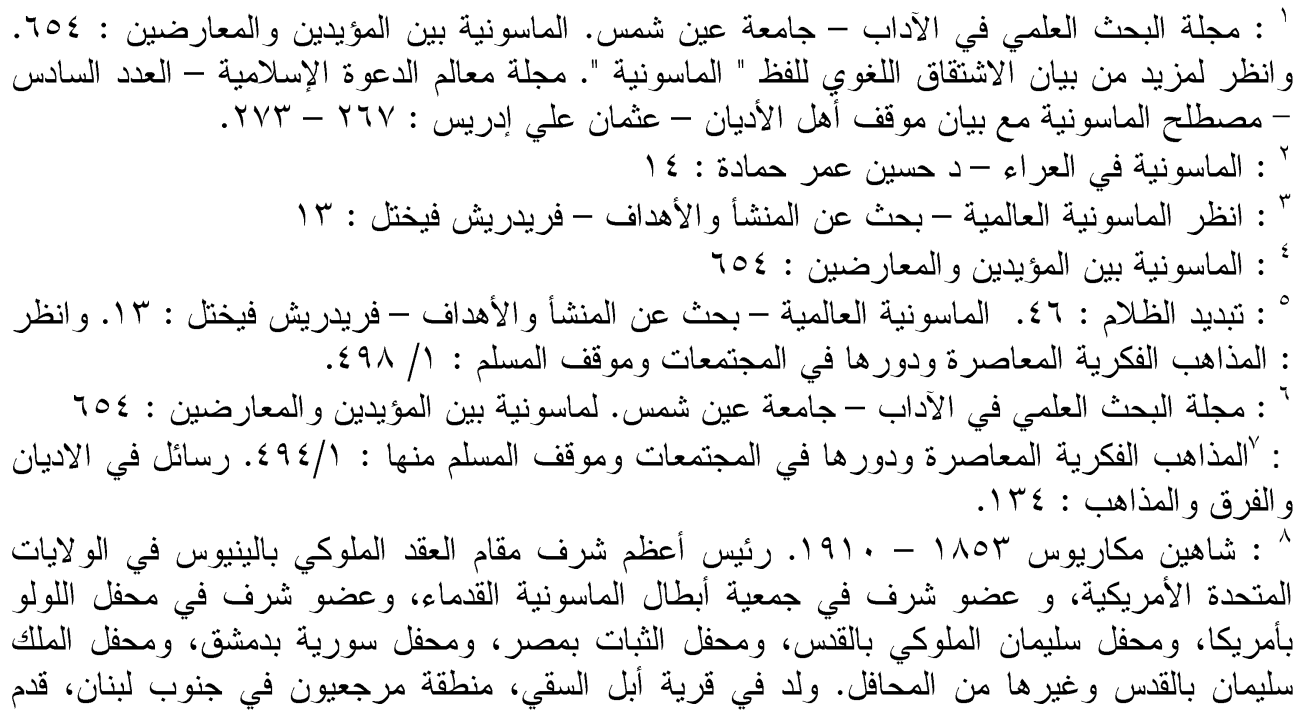




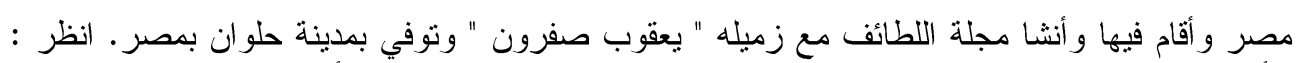

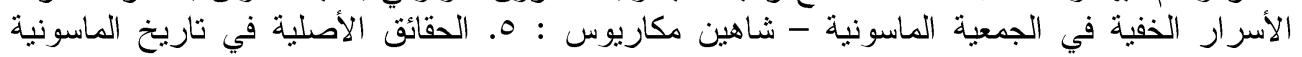

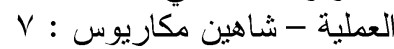

"

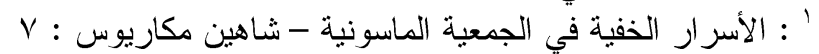

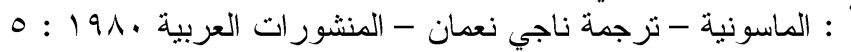

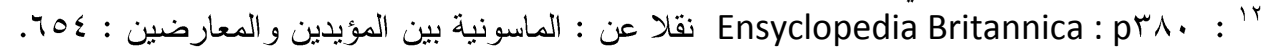

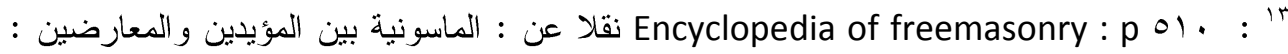

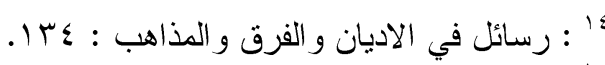

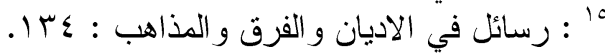

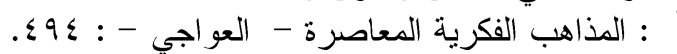

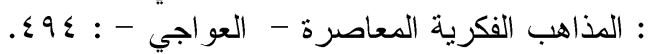

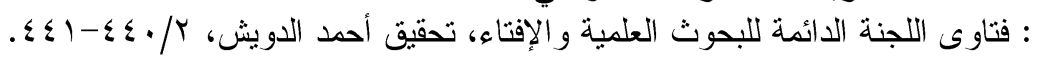

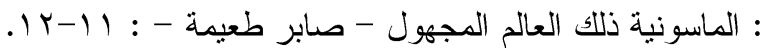

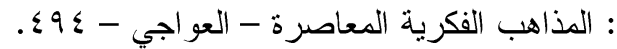

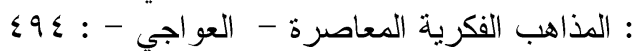

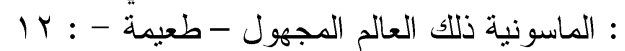

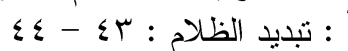

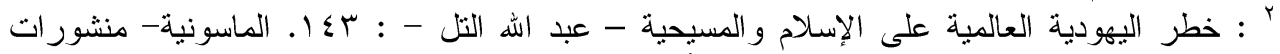

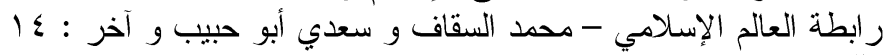

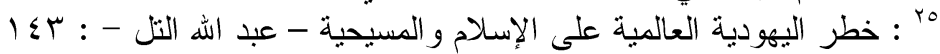

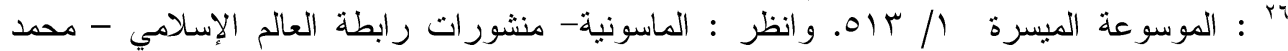

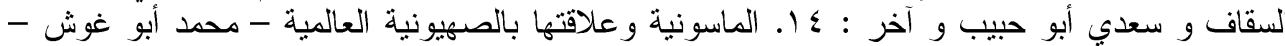
TOV : الماسونية وبين المؤيدين و المعارضين : VV

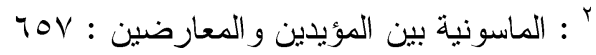

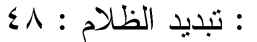

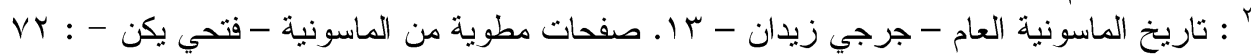

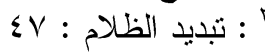

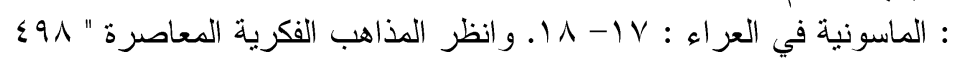

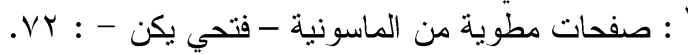

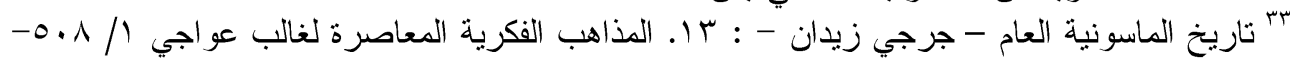

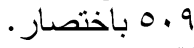

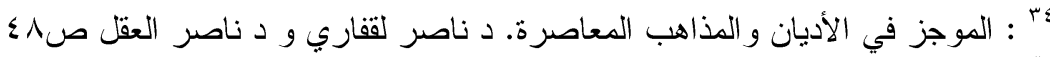

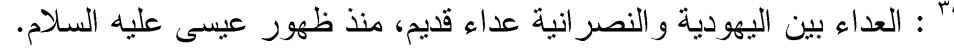

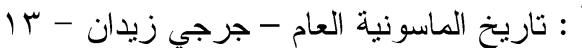

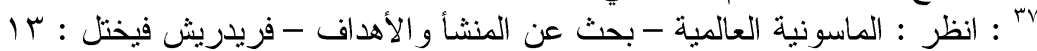

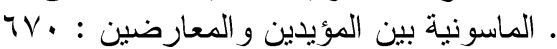

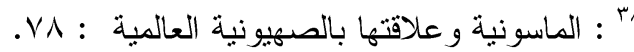

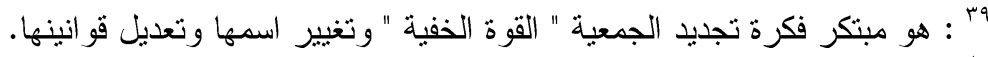

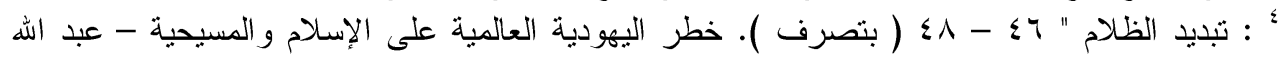




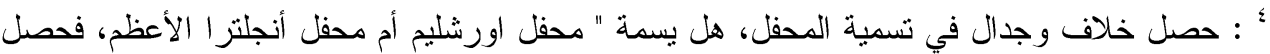

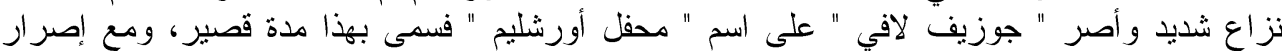
الأكثرية نم استبدال الاسم باسم " محفل إنكلترا الأعظم ". انظر تبديد الظلام أو أصل الماسونية :

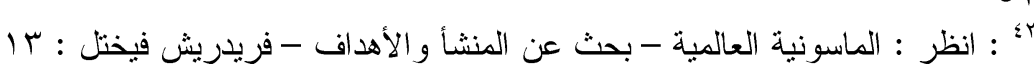

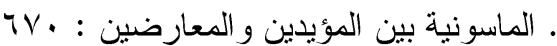

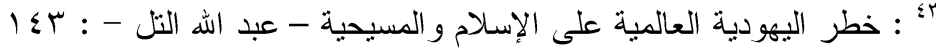

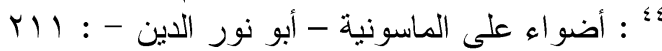

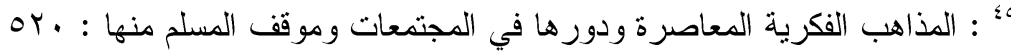

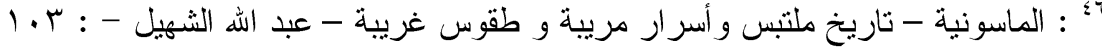

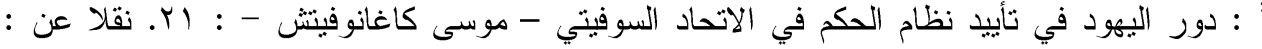

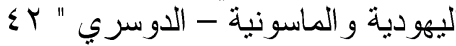

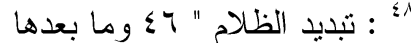
؛

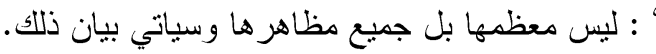

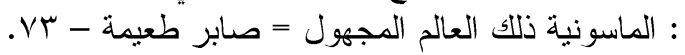

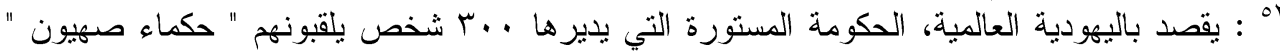

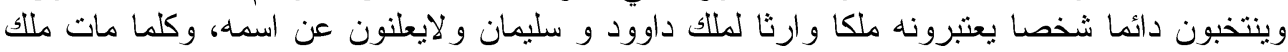
عينوا بدلا عنه من بين أحبار اليهود. انظر : خطر الئهودية العالمية على الإسلام و المسيحية - عبد الله

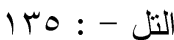

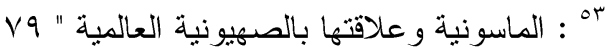

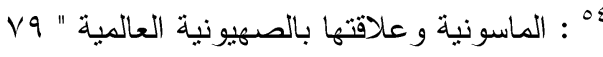

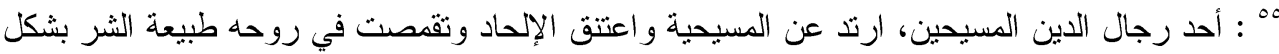

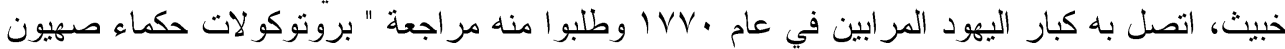

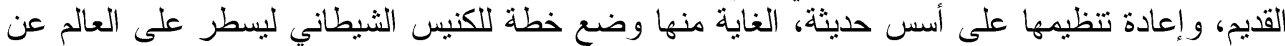
طريق فرض عقيدة الإلحاد. اليهود وراء كل جريمة - ولئم كار - شرح وتعليق : خير الله الطلفاح - :

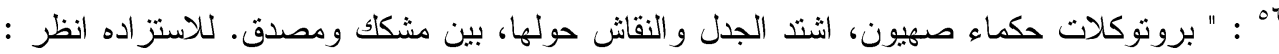

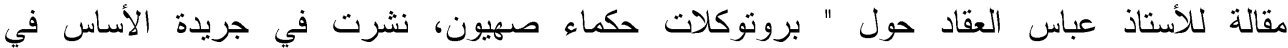

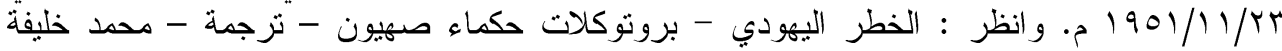

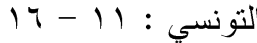

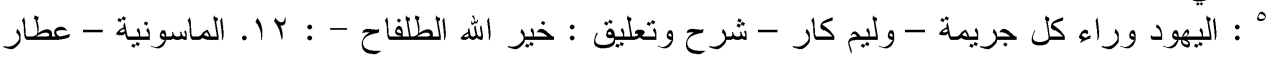

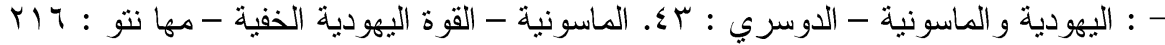

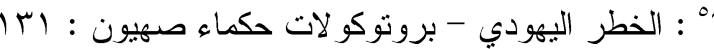

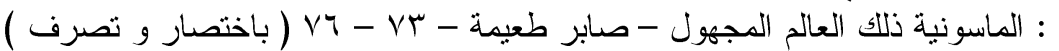

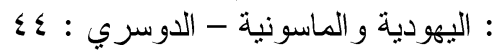
VY : صفحات مطوية من الماسونية

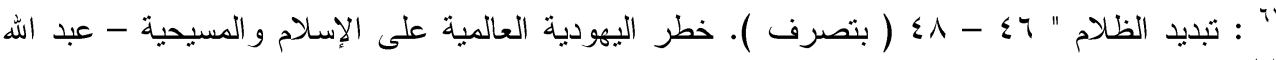

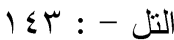
"آ" : المذاهب الفكرية المعاصرة : :

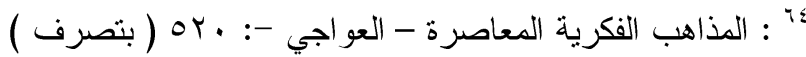

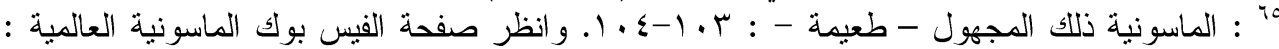

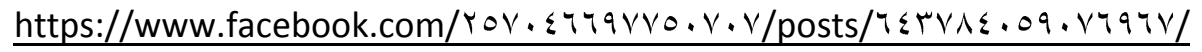




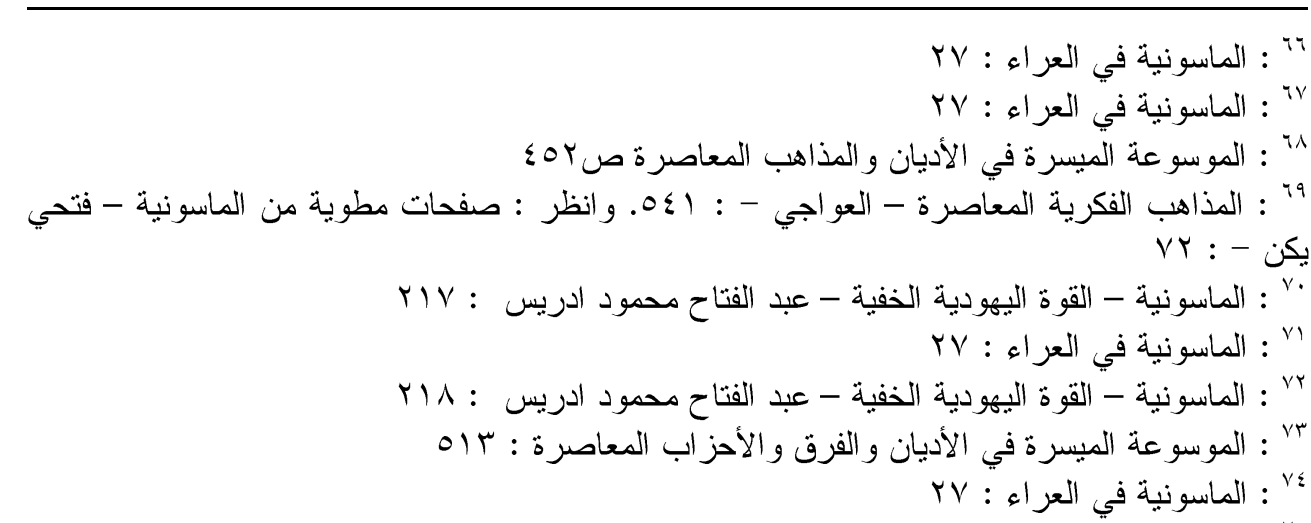

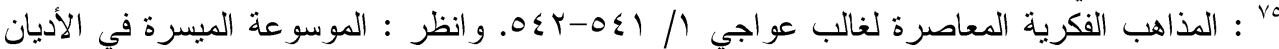

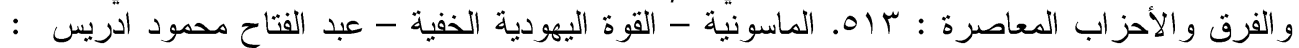

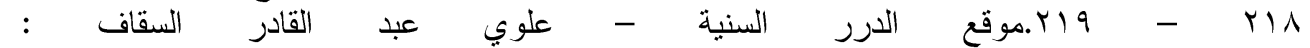
https://www.dorar.net/mazahib/ $\wedge \wedge / \% D \wedge \% A B \% D \wedge \% A \vee \% D q \% \wedge ० \% D q \% \wedge \uparrow \% D \wedge \% A \vee:-$ $\% D q \% \wedge) \% D \wedge \% B \backslash \% D q \% \wedge r-$

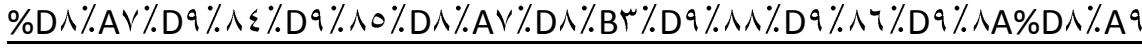

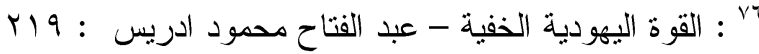

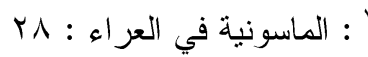

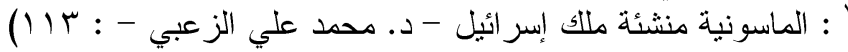

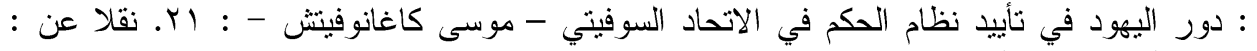

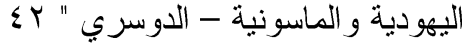

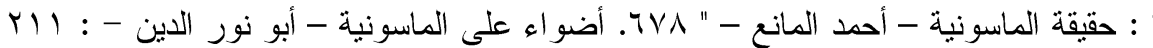

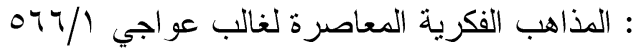

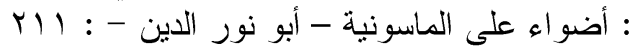

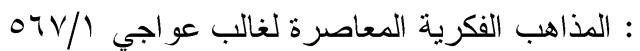

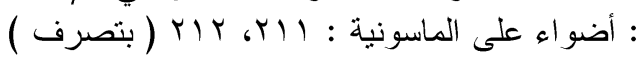

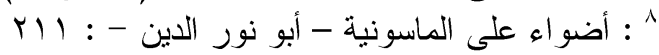

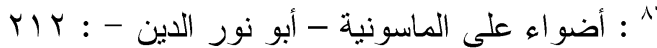

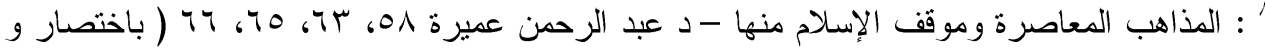

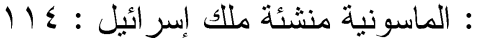

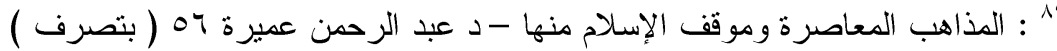

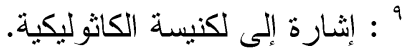

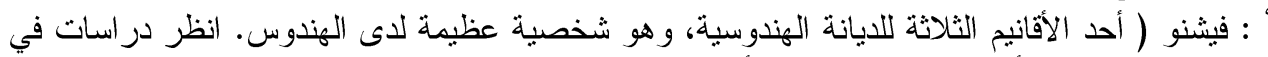

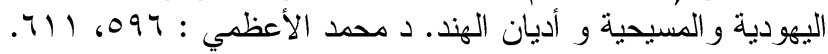
المو : الماسونية منشئة ملك إسر ائيل : 110

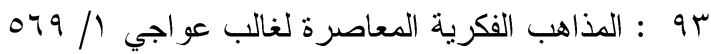
ع 9 : الماسونية منشئة ملك إسر ائيل : 110 90

97 : 97

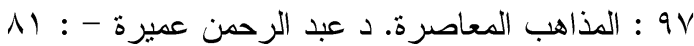

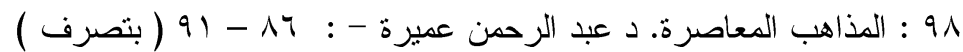




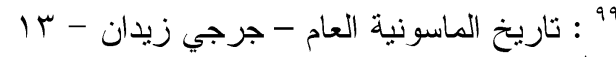

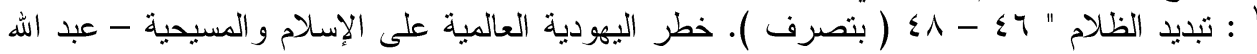

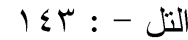

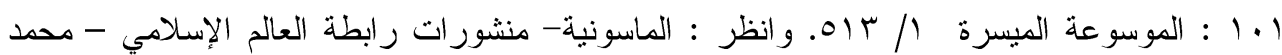

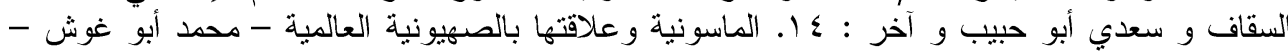

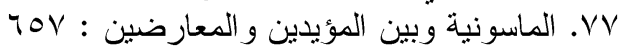

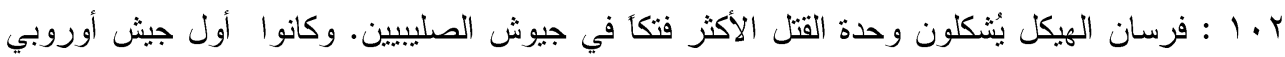

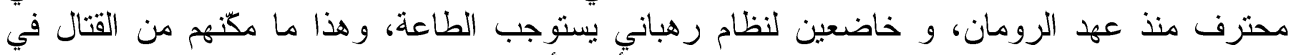

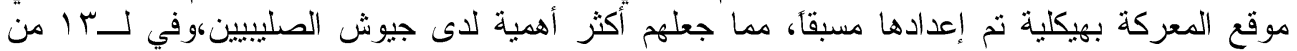

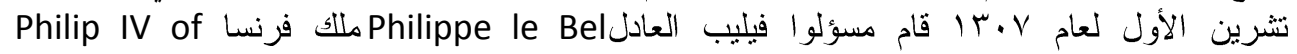

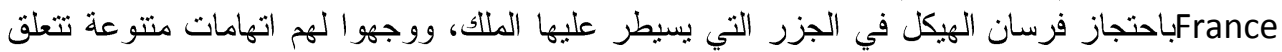

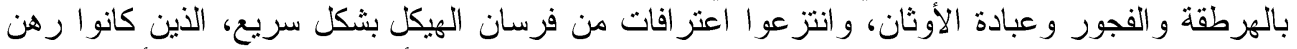

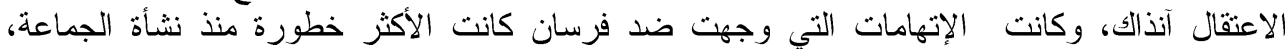

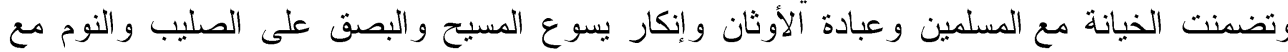
الشيطان و أكل رفات موتاهم وتخصيب العذارى و الكثير من الأفعال الثاذة.

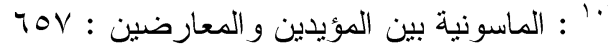

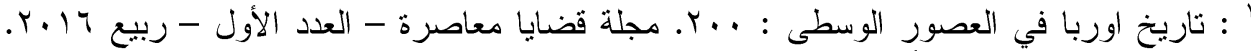

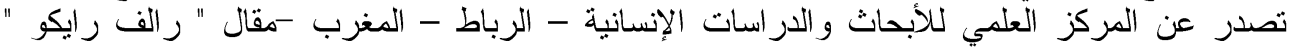

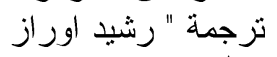

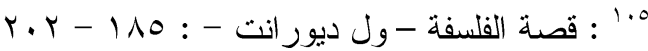

7 ـ1 : المصلح مارت لوثر - حياته وتعاليمه - بحث تاريخي عقائدي لاهوني - الدكتور القس حنا جرجس - : 11: (1)

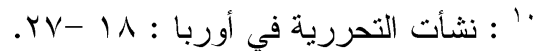

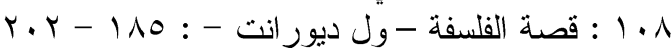

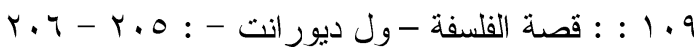

• 11 : انظر : شكسبير - ديفيد بيفنجتون - ترجمة عبد المقصود عبد الكريم : V - - .

SVI - EV· : - 111 : مذاهب فكرية معاصرة - مزروعة

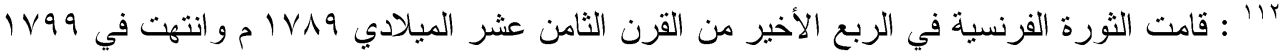

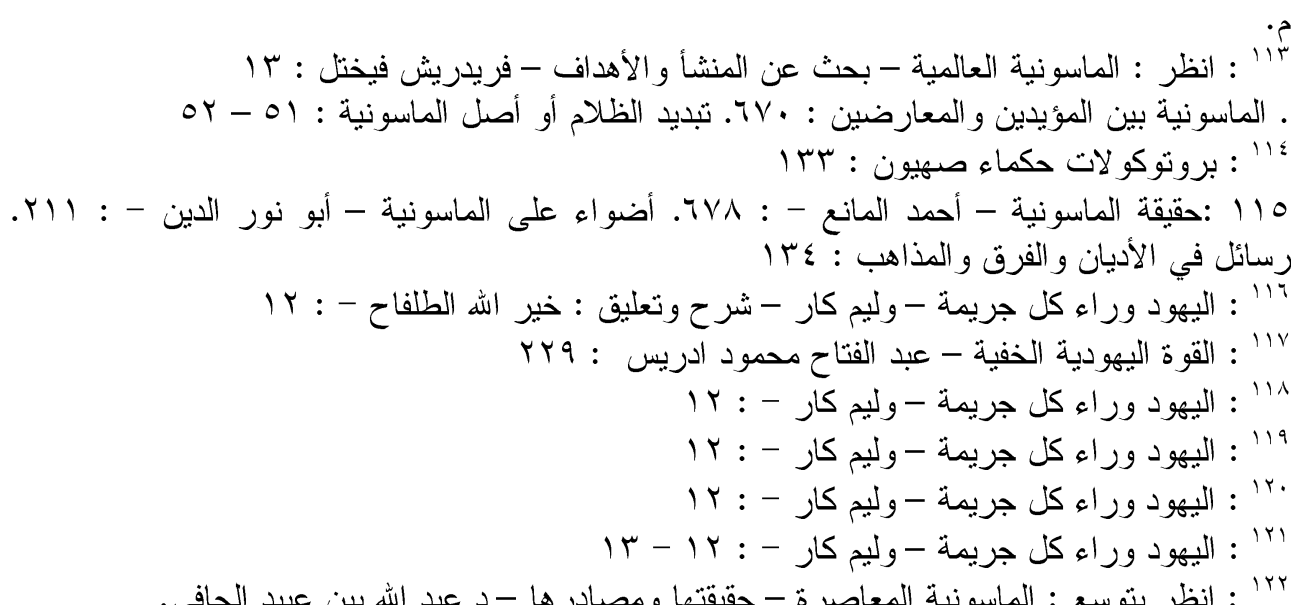

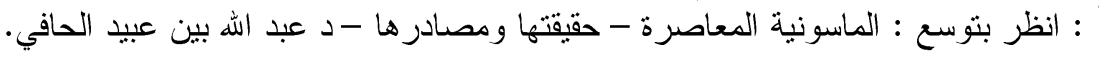

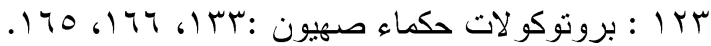




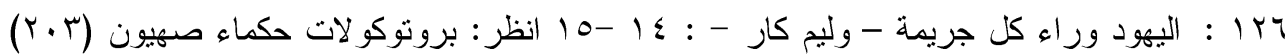

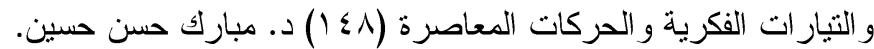

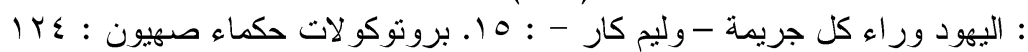

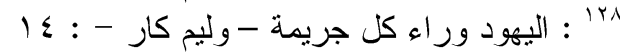

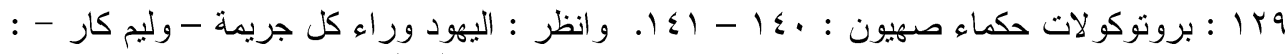

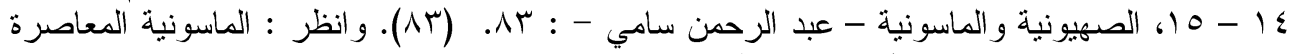

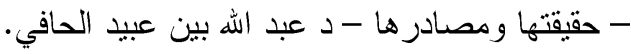

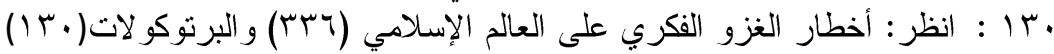

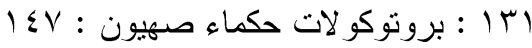

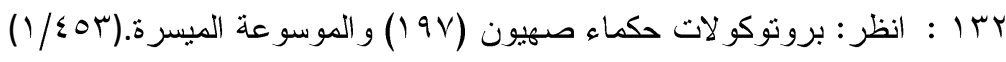

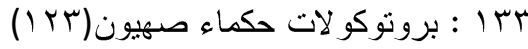

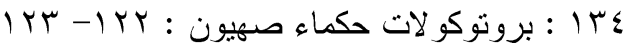

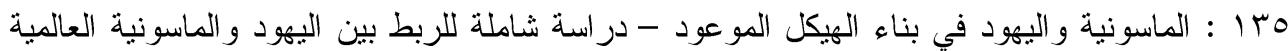

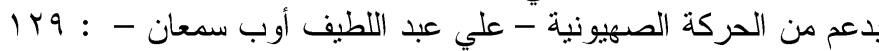

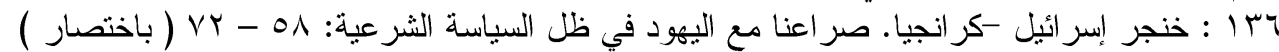

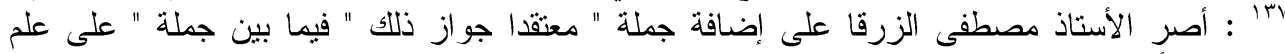

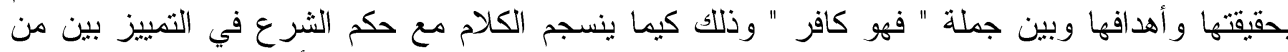

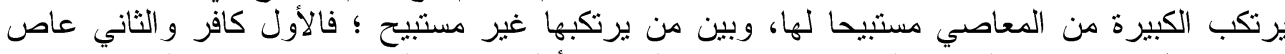

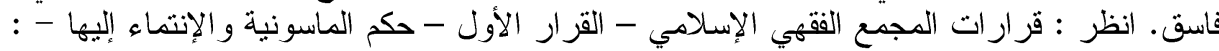

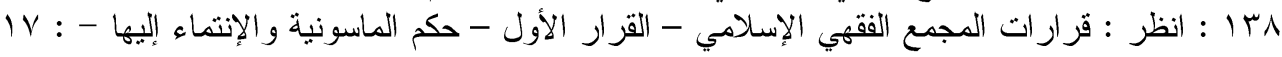

r. -

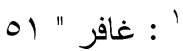

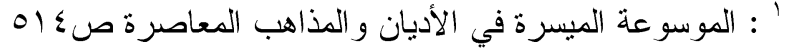

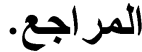

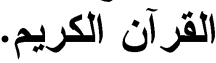

المصادر و المر اجع المرنج

\begin{tabular}{|c|}
\hline الأسر ار الخفية في الجمعية الماسونية - شاهين مكاريوس \\
\hline أضو اء على الماسونية - أبو نور الدين - \\
\hline الصهيونية و الماسونية - عبد الرحمن سامي \\
\hline اليهود ور اء كل جريمة - وليم كار - شرح وتعليق - خير الله الطلفاح. دار الكتاب العربي \\
\hline تاريخ الماسونية العام - جرجي زيدان - \\
\hline تبديد الظلام أو أصل الماسونية - عوض الخوري \\
\hline الحقائق الأصلية في ناريخ الماسونية العملية - شاهين مكاريوس \\
\hline حقيقة الماسونية - أحمد المانع - \\
\hline الخطر اليهودي - بروتوكلات حكماء صهيون - ترجمة - محمد خليفة التونسي- \\
\hline خطر اليهودية العالمية على الإسلام و المسيحية - عبد الله التل - \\
\hline خنجر إسر ائيل -كر انجيا، ط الأولى، 901 ام، الكتب التجاري، بيروت، \\
\hline در اسات في اليهودية و المسيحية و أديان الهند. د محمد الأعظمي \\
\hline دور اليهود في تأييد نظام الحكم في الاتحاد السوفيتي - موسى كاغانوفيتش - \\
\hline رسائل في الاديان و الفرق و المذاهب : عسا. \\
\hline
\end{tabular}




\begin{tabular}{|c|}
\hline آسر \\
\hline كاسونية - فتحي بكن - \\
\hline 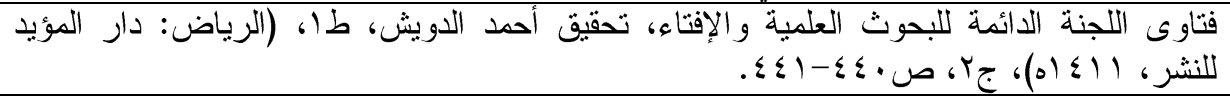 \\
\hline قرار ات المجمع الفقهي الإسلامي - القرار الأول - حكم الماسونية و الإنتماء إليها - \\
\hline 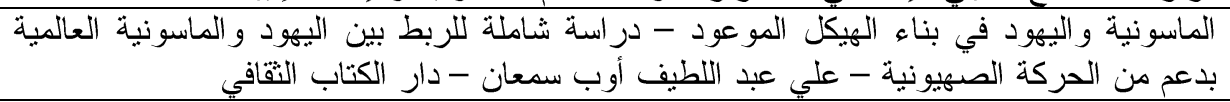 \\
\hline الماسونية المعاصرة - حقيقتها ومصادر ها - د عبد الله بين عبيد الحافي. \\
\hline الماسونية - أحمد عبد الغفور عطار \\
\hline الماسونية - القوة اليهودية الخفية - مها نتو - \\
\hline الماسونية - تاريخ ملتبس و أسر ار مريبة و طقوس غريبة - عبد الله الشهيل - \\
\hline الماسونية - ترجمة ناجي نعمان - المنشور ات العربية ، 191 \\
\hline أهل الأديان - عثمان علية معالم الدعوة الإسلامية - العدد السادس - مصطلح الماسونية مع بيان موقف \\
\hline الماسونية العالمية - بحث عن المنشأ و الأهداف - فريدريش فيختل \\
\hline 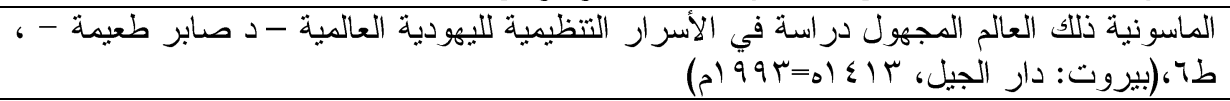 \\
\hline الماسونية في العر اء - د حسين عمر حمادة \\
\hline الماسونية- منشور ات ر ابطة العالم الإسلامي - محمد السقاف و سعدي أبو حبيب و آخر \\
\hline الماسونية منشئة ملك إسر ائيل - د. محمد علي الزعبي مؤسسة مطابع معتوق الطبعة \\
\hline الماسونية و علاقتها بالصهيونية العالمية - محمد أبو غوش - \\
\hline مجلة البحث العلمي في الآداب - جامعة عين شمس. الماسونية بين المؤيدين و المعارضين \\
\hline المذاهب الفكرية المعاصرة ودورها في المجتمعات وموقف المسلم - د غالب العو اجي \\
\hline المذاهب المعاصرة وموقف الإسلام منها لعبد الرحمن عميرة - \\
\hline الموجز في الأديان و المذاهب المعاصرة لناصر لقفاري وناصر العقل \\
\hline الموسو عة الميسرة في الأديان و المذاهب المعاصرة \\
\hline لمونية - عبد الرحمن الدوسري - \\
\hline
\end{tabular}

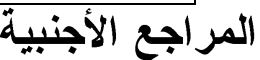

Encyclopedia of freemasonry : $p 01$.

Ensyclopedia Britannica : p $\mathrm{\mu}$.

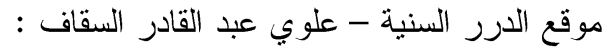

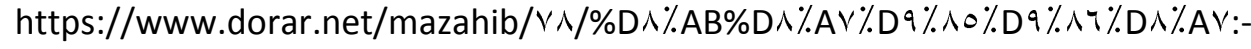

$\% D q \% \wedge) \% D \wedge \%$ В \% \%q\%^r-

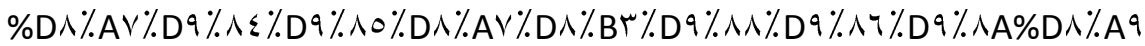

موقع الفيس بوك : الماسونية العالمية.

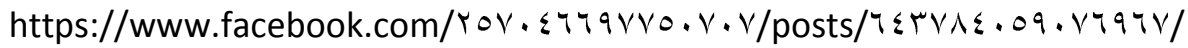

